\title{
Hormonal regulation of immune modulators in human breast tissue
}

\author{
Vivian Morad
}

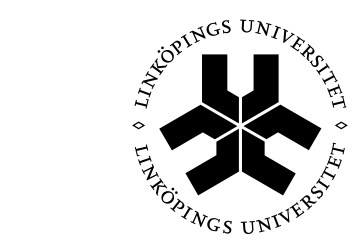

\section{Linköping University \\ FACULTY OF HEALTH SCIENCES}

\author{
Division of Clinical Sciences \\ Department of Clinical and Experimental Medicine \\ Linköping University, SE-581 85 Linköping, Sweden
}

Linköping 2015 
(C) Vivian Morad, 2015

ISBN: 978-91-7519-055-6

ISSN: 0345-0082

Published articles have been reprinted with permission from the publishers:

Endocrine Press, an imprint of the Endocrine society.

Printed in Sweden by LiU-tryck, Linköping 2015 


\section{To my family}

"To keep a lamp burning, we have to keep putting oil in it." Mother Teresa 


\section{SUPERVISOR}

Charlotta Dabrosin, MD, PhD, Professor

Division of Clinical Sciences

Department of Clinical and Experimental Medicine

Faculty of health sciences, Linköping

\section{CO-SUPERVISOR}

Christina Ekerfelt, PhD, Professor

Division of inflammationsmedicin (AIM)

Department of Clinical and Experimental Medicine

Faculty of health sciences, Linköping

\section{OPPONENT}

Malin Sund, MD, PhD, Professor

Division of surgery

Department of surgical and perioperative Sciences

Faculty of Medicine, Umeå

\section{COMMITTEE BOARD}

Tommy Sundqvist, PhD, Professor

Division of Clinical Sciences

Department of Clinical and Experimental Medicine

Faculty of health sciences, Linköping

Mårten Fernö, PhD, Professor

Division of Oncology

Department of Clinical Sciences

Faculty of Medicine, Lund

Agneta Jansson, PhD, Docent

Division of Clinical Sciences

Department of Clinical and Experimental Medicine

Faculty of health sciences, Linköping 


\section{Abstract}

Breast cancer is the most common form of cancer and the second leading cause of malignancy-associated death in women worldwide. Estrogens are the main sex hormones in women. They are essential for the development and function of normal breast mammary glands; however, prolonged exposure to estrogens increases the risk of breast cancer development and progression. Approximately two-thirds of all breast cancer patients are positive for estrogen receptor (ER), but only $50 \%$ of those cases can benefit from antiestrogen therapy.

In this thesis we investigated the effects of estrogen, diet modification, and anti-estrogen drugs on several immune modulators in normal human breast tissue. We used the microdialysis technique to sample the immune modulators in situ in normal human breast tissue, in malignant breast tissue, and in tumor tissue from both the immune competent mice with murine breast cancer and immune deficient mice bearing human breast tumors. Furthermore, we also used ex vivo culture of normal breast tissue and in vitro cell culture of breast cancer cell lines. A combined cell culture (co-culture) of breast cancer cell lines, together with the primary mature adipocytes, was also used in this thesis.

In Paper I and Paper II, our results suggested that estrogen exerted both proinflammatory and pro-tumorigenic effects in normal human breast tissue. Estradiol increased extracellular

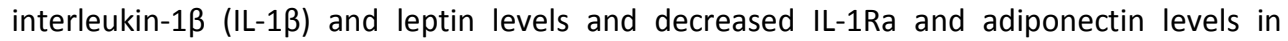
normal human breast tissue. In contrast, tamoxifen decreased IL-1 $\beta$ and leptin levels and increased IL-1Ra and adiponectin levels, shifting the environment towards an antiinflammatory and antitumorigenic state. Diet modification with flaxseed for $\mathbf{3 0}$ days also increased IL-1Ra levels, creating an anti-inflammatory environment in normal breast tissue. In the breast cancer tissue, we found that extracellular IL-1 $\beta$ levels and leptin levels were significantly higher, whereas adiponectin levels were significantly lower, compared with normal adjacent breast tissue, which suggested a more proinflammatory state.

In the third paper, our in vivo investigation of normal breast tissue revealed significant correlations between vascular endothelial growth factor (VEGF) and leptin, IL-1 $\beta$ and leptin, and between VEGF and IL-1ß. No correlations were found in the abdominal subcutaneous (s.c.) fat tissue. Our in vitro inhibition experiments suggested that VEGF was a potent regulator of leptin, but that leptin was not a potent regulator of VEGF. Co-culture per se altered the release of VEGF and leptin and enhanced the effects of estradiol, compared with monocultures of the included cell types.

In conclusion, the results presented in this thesis will increase the overall understanding of the role of estrogens in breast cancer, which may be useful in future treatment studies. 


\section{Table of Contents}

Abstract __ 5

Populärvetenskaplig sammanfattning ___ 9

List of papers __ 11

Abbreviations __ 13

Introduction __ 15

Breast cancer

Etiology and risk factors __ 16

Diagnosis and treatment __ 16

The breast___ 17

Sex steroids___ 18

Estrogen and breast cancer ___ 19

Tamoxifen 119

Fulvestrant 20

Tumor microenvironment ___ 21

Inflammation _ 21

Inflammation and breast cancer _ 22

The interleukin-1 family _ 23

$\mathrm{IL}-1 \alpha, \mathrm{IL}-1 \beta$, and IL-1Ra__ 24

Adipokines _ 25

Leptin and the leptin receptor

Adiponectin and the adiponectin receptors

Leptin/adiponectin ratio __ 26

Angiogenesis 27

Vascular endothelial growth factor (VEGF) _ 27

Nutrition and breast cancer ___ 28

Aims of this thesis ___ 29

Comments on methods ___ 31

Cancer cell lines __ 31

Human primary cells __ 31

Human tissue in culture ___ 32

Microdialysis _ 33

Human subjects __ 35

Animal models 37

MMTV-PyMT mouse model __ 37

The nude mouse xenograft model

Immunohistochemistry _ 40 
ELISA

Statistics 44

Results and discussion 45

Conclusions 52

Reflections and future aspects 53

Acknowledgements 55

References 57 


\section{Populärvetenskaplig sammanfattning}

Bröstcancer är den vanligaste cancerformen hos kvinnor. I Sverige diagnosticeras drygt 8000 nya fall varje år vilket betyder att en av nio kvinnor löper risk för att drabbas av bröstcancer under sin livstid. Trots stora framgångar i utvecklingen av diagnostik och behandlingsmetoder, är bröstcancer idag den näst vanligaste dödsorsaken för kvinnor i västvärlden. Bara i Sverige dör omkring 1400 kvinnor av bröstcancer varje år.

Orsakerna till bröstcancer är inte helt klarlagda men mycket talar för att omgivningsfaktorer såväl som livsstilsmönster ökar risken att drabbas då bara 5-10 procent av fallen kan påvisa en ärftlig faktor. Livsstilsfaktorer innefattar bland annat hormonella faktorer så som tidig pubertet, sent klimakterium, hög ålder vid första graviditet, barnlöshet och användning av hormonella mediciner, men även övervikt och alkoholkonsumtion ökar risken för bröstcancer. Upp till 80 \% av alla bröstcancer uttrycker östrogenreceptorn och är således beroende av det kvinnliga könshormonet östrogen för sin tillväxt. Patienter med sådana tumörer kan därför ha nytta av anti-östrogen behandling. Trots att exponering för östrogen är en sådan viktig faktor både för utveckling och fortsatt tillväxt av bröstcancer är de exakta mekanismerna för detta samband inte helt klarlagda.

Syftet med denna avhandling var att studera östrogenets roll i reglering av proteiner (IL-1, adipokiner och VEGF) som är viktiga för immunförsvaret och kärlnybildning i normal bröstvävnad och i bröstcancer.

I det första och andra delarbetet, fann vi att östrogen ökar utsöndringen av IL-1ß och leptin och minskar utsöndringen av IL-1Ra och adiponectin i normal bröstvävnad. Anti-östrogenet tamoxifen omvänder förhållandet genom att öka utsöndringen av IL-1Ra och adiponectin och minska utsöndringen av IL-1 $\beta$ och leptin. En ökning i IL-1 $\beta$ och leptin medför en proinflammatorisk mikromiljö i bröstvävnaden. Höga nivåer av leptin och IL-1 $\beta$ detekterades i bröstcancer hos kvinnor jämfört med nivåerna i normal näraliggande bröstvävnad. Dessa resultat har validerats i en odlingsmodell av humana bröstvävnadsbiopsier i delarbete 1 och 2 och med djurförsök i delarbete 2.

I delarbete tre fann vi signifikanta korrelationer mellan VEGF och leptin, IL-1 $\beta$ och leptin samt VEGF och IL-1 i normal bröstvävnad. In vitro neutraliseringsexperiment med antikroppar mot VEGF och leptin, indikerade att VEGF reglerar leptin och inte tvärtom. Bröstcancerceller som odlades tillsammans med mogna fettceller (adipocyter) ökade produktionen av VEGF och leptin samt ökade östrogenets effekt på båda dessa modulatorer.

Sammanfattningsvis visar avhandlingen att östrogen påverkar utsöndringen av flera viktiga proteiner (IL-1, leptin och adiponectin) i normal bröstvävnad och att viktiga interaktioner förekommer mellan dessa proteiner i bröstvävnadens mikromiljö. Avhandlingens resultat bidrar till den grundläggande förståelsen för hormonberoende förändringar i bröstet. Detta är viktigt för framtagandet av metoder som kan minska risken för utveckling och fortsatt tillväxt av bröstcancer. 


\section{List of papers}

The paper list included in this thesis:

I. Abrahamsson A, Morad V, Saarinen NM and Dabrosin C.

Estradiol, tamoxifen, and flaxseed alter IL-1 $\beta$ and IL-1Ra levels in normal human breast tissue in vivo.

J Clin Endocrinol Metab. (2012) 97: E2044-E2054.

II. Morad V, Abrahamsson A, and Dabrosin C.

Estradiol affects extracellular leptin:adiponectin ratio in human breast tissue in vivo. J Clin Endocrinol Metab. (2014) 99: 3460-7.

III. Morad V, Abrahamsson A, Kjölhede P, and Dabrosin C.

Correlation between vascular endothelial growth factor and leptin in normal human breast tissue in vivo.

Manuscript 2015. 


\section{Abbreviations}

AJCC the American Joint Committee on Cancer

AdiopR1 Adiponectin receptor 1

AdiopR2 Adiponectin receptor 2

DAB 3,3'-diminobenzidine

E1 Estrone

E2 Estradiol

E3 Estriol

ER Estrogen receptor

Fas $\quad$ Fulvestrant (Faslodex)

G-CSF Granulocyte colony-stimulating factor

IGF Insulin growth factor

IHC Immunohistochemistry

IL-1 Interleukin-1

IL-1RAcP IL-1 receptor accessory protein

IL-1Ra IL-1 receptor antagonist

IL-1RI IL-1 receptor type I

IL-1RII IL-1 receptor type II

IL-8 Interleukin-8

JAK2 Janus tyrosine kinase 2

MAPK Mitogen activated protein kinase

MMTV Mouse mammary tumor virus promoter

NF-KB Nuclear factor-kB

NLS Nuclear localization sequence

NSAIDs Non-steroidal anti-inflammatory drugs

Ob-R Leptin receptor

PCR Polymerase chain reaction

PPAR $\alpha$ Peroxisome proliferator-activated receptor- $\alpha$ 
PI3K Phosphatidylinositol 3-kinase

PyMT Polyoma middle T antigen

s.c. Subcutaneous

SDS-PAGE Sodium dodecyl sulfate polyacryamid gel electrophoresis

STAT3 Signal transducer and activator of transcription 3

Tam Tamoxifen

TGF- $\alpha \quad$ Transforming growth factor-alpha

TGF- $\beta \quad$ Transforming growth factor-beta

TIR Toll/IL-1 receptor domain

TNF- $\alpha \quad$ Tumor necrosis factor-alpha

TSP-1 Thrombospondin-1

VEGF Vascular endothelial growth factor

VEGFR VEGF receptor 


\section{Introduction}

Cancer is an uncontrolled growth of cells. Transformation from a normal cell to an abnormal cancer cell was characterized by distinctive biological capacities, as summarized by Hanahan and Weinberg (1). Cancer initiation is the first step of this complex multistep process, where alterations in the genetic and epigenetic materials occur spontaneously or by cancerous agents such as chemicals, radiation, or pathogenic agents (2). Genetic alteration may lead to the abnormal proliferation of a single cell and further expansion of this population. Cancer progression continues when mutations or alterations in expression of some key genes, such as oncogenes and tumor suppressor genes, arise from an uncontrolled proliferation (3). Some of these mutations have survival advantages and consequently become dominant and clonally selective within the tumor population (4). Without growth stimulation of new blood vessels, known as angiogenesis, the accumulation of abnormal clonal cells in their normal place (in situ) may stagnate for extended periods of time (benign tumors). Angiogenesis is essential for tumor growth and development, because the blood provides tumors with nutrients and oxygen. Some cancers are invasive, with the ability to destroy and invade the surrounding organs, whereas metastatic tumors spread to distant organs by entering the bloodstream or lymphatic system.

There are over 200 different types of cancer, with extensive heterogeneity of different characteristics within each type. Cancers are categorized depending upon the cell types from which they originated.

\section{Breast cancer}

In 2012, 14.1 million cancer cases were reported worldwide. Each year, 25\% (1.7 million) of all newly diagnosed cancers in women involve breast cancer, which makes this disease the most common form of cancer in women. Despite major improvements in diagnoses and treatments, breast cancer is still the second leading cause of cancer-related death among women after lung cancer $(5,6)$. In Sweden, more than 8,000 women are diagnosed with breast cancer every year, which means that one in every nine women will be diagnosed with breast cancer during her lifetime. Although the mortality rate of breast cancer in Sweden has slowly decreased likely due to the improved treatment strategies, approximately 1,400 women still die from breast cancer every year.

Breast cancer begins as an uncontrolled cell growth in breast tissue. The cancer usually starts in the epithelial cells of the milk ducts, where it is classified as ductal carcinoma, or in the milk producing glands (lobules), where it is classified as lobular carcinoma. Breast cancer may also originate from other cell types in the breast, such as stromal, vascular, and fat cells, but the originations from these types of cells are extremely rare (Fig. 1). Breast cancer is usually divided into noninvasive carcinoma in situ, or invasive breast cancer, depending on the ability of the cancer cells to cross the basement membrane and invade the surrounding tissues, or metastasize to the other parts of the body. The most common form of breast cancer is invasive ductal breast cancer, which accounts for $70-80 \%$ of all cancer cases, while the invasive lobular breast cancer accounts for only $5-15 \%$ of all cases (7). 


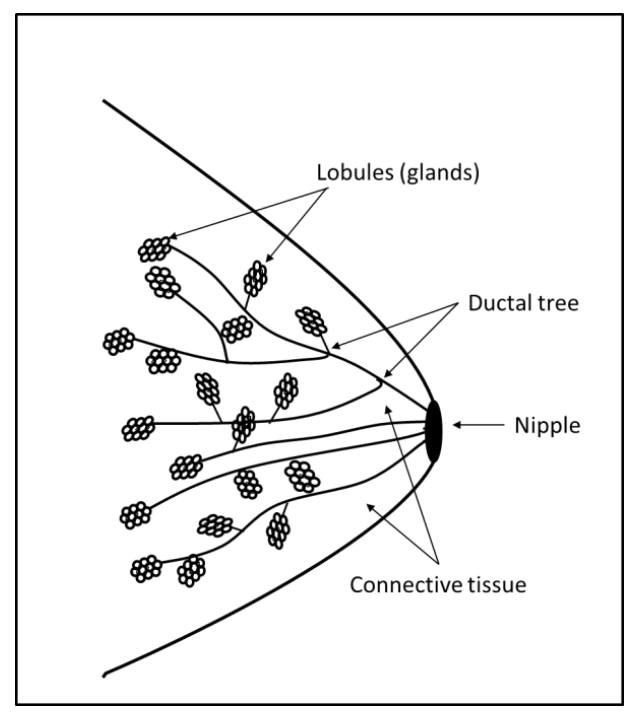

Figure 1. A schematic picture illustrating the breast anatomy.

\section{Etiology and risk factors}

The exact etiology of breast cancer is still unknown, but several risk factors are recognized for their associations with this disease. The incidence of breast cancer varies in different regions of the world, with the highest incident rate in the Western world. Studies of migrants moving from the low risk countries to high risk countries have shown an increase in breast cancer rates, indicating that environmental factors may have a significant influence (8). Age, gender, and personal lifestyle, such as alcohol consumption and obesity, are strongly correlated with breast cancer incidence. Epidemiological studies have also linked long-term hormone exposure, in early menarche before 12 years of age, late menopause after 55 years of age, and hormone replacement therapy with the increased risk of breast cancer $(9,10)$. Furthermore, early parity showed protective effects against the development of breast cancer, and these effects increased with multiparity $(11,12)$. Only $5-10 \%$ of all breast cancers were associated with inherited genetic factors, even though $20-30 \%$ of all breast cancer patients have a family history of this disease, or other cancer forms such as ovarian, uterine, or colon cancer. The most well-known genetic factors include germline mutations in the BRCA1, BRCA2, and TP53 genes (13).

\section{Diagnosis and treatment}

Breast cancer is typically detected by the discovery of a lump in the breast or by a screening examination, but definitive diagnosis is based on the so-called "triple diagnostics", which include an examination, radiological screening (mammography and ultrasound), and biopsies (fine needle aspiration biopsy, core biopsy, and surgical biopsy) (14). Different treatments are available for breast cancer patients, but the specific treatment depends on several prognostic and predictive factors. Prognostic factors, including aggressive tumor growth, high proliferation, and histological grade, suggest the patient's prognosis without treatment (15), while the predictive factors, including the presence of estrogen receptor 
(ER), progesterone receptor (PR), and human epidermal growth factor receptor 2 (HER2/neu), predict the most effective treatment(s) $(16,17)$. Other factors such as age, the general health of the patient, the spread of the tumor, and classification using the tumor node metastasis (TNM) system, are also considered before starting therapy $(18,19)$.

Surgery, radiation, chemotherapy, hormone therapy, and targeted therapy are all possible treatments used for breast cancer (18). Surgery, for complete removal of the malignant tissue, is often followed by radiation to destroy local residual tumor tissue (20-23). Adjuvant therapies, including chemotherapy, hormone therapy (such as tamoxifen and aromatase inhibitors), targeted therapy (anti-HER2), and radiotherapy are used alone or in combination to reduce the risk of local and distant metastases in other parts of the body (24-27). Neoadjuvant therapy is another type of treatment used to shrink the tumor before the surgery.

\section{The breast}

The development of the female breast starts during early embryonic stages and achieves full differentiation and maturation by the end of first full-term pregnancy (28). Before birth, the first structures of the mammary glands are present, and a primitive ductal system develops. The mammary glands are surrounded by connective tissue, which contains fibroblasts, immune cells, and fat cells, and is infiltrated by blood and lymph vessels. Hormones secreted by the ovaries and pituitary, including estrogen, progesterone, and several growth factors, initiate breast development by affecting both the epithelial cells and the stromal cells (29). At puberty, the simple ductal system starts to grow and divide into terminal end buds in response to the hormonal changes. The maturation of the branching structures continues to form smaller ducts, ending in a cluster of alveoli, and creating the simplest lobule form, Lob 1 (28). The epithelial cells in Lob 1 express relatively high levels of estrogen receptor (ER) and progesterone receptor (PR), and are highly proliferative, making them sensitive to cancerous agents and susceptible to malignant transformation (30). During pregnancy, the lobule changes to type 2 (Lob 2) and type 3 (Lob3), which are more mature and complex then Lob 1. Transformation of lobules reaches its full differentiation as Lob 4, with mature glands producing and secreting milk during lactation. Lob 3 and 4 are thought to be protective against neoplastic transformation, because they were shown to have the lowest proliferative activity and lowest rate of carcinogen binding to DNA (30). However, the mammary system regresses back to Lob 3 after lactation. This regression will continue during and after menopause, and primarily returns to Lob 1 for both parous women and nulliparous women. The cellular differentiation obtained from early pregnancy in parous women may explain the protection gained against the development of breast cancer, although similar structural changes of the mammary system occur in all women after menopause $(31,32)$. 


\section{Sex steroids}

Steroid hormones, such as estrogens, androgens and progesterone, are generally recognized for their role in normal reproductive tissue development, but in recent years their involvement in other functions such as metabolism, immune responses, inflammation, and salt and water balance has been reported (33). Estrogens are the main sex hormones in women. In addition to the ovaries, which are the primary producers of estrogens, other organs such as the liver, adrenal gland, adipose tissue (predominantly in postmenopausal women), and breast tissue also produce estrogens, but to a lesser extent (34). Estrogens are synthesized from androgens, with cholesterol being the starting molecule (35). Cholesterol is converted to androstenedione and testosterone, which are then catalyzed by aromatase enzymes to estrone (E1) and estradiol (E2), respectively. E1 and E2, together with estriol (E3), represent the three natural forms of estrogens. E2 is the most important hormone for nonpregnant women during the period from menarche until the menopause. $\mathrm{E} 1$ is the main sex hormone in postmenopausal women, while E3 is abundant in pregnant women.

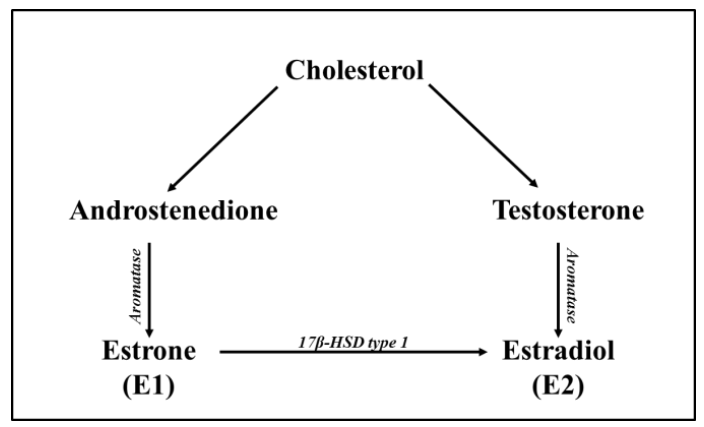

Figure 2. Sex steroid biosynthetic pathways. Conversion of cholesterol into estrogens.

Estrogens, as all other steroid hormones, can passively diffuse across the cell membrane into all cells of the body, but only activate cells containing the estrogen receptor (ER). However, some estrogen receptors expressed on the cell surface, called membrane estrogen receptors (mER), can also be activated by estrogen (36-38). Two different forms of $E R$ exist, ER $\alpha$ and ER $\beta$. The ERs are coded by different genes, but have similar affinities for E2. Studies of knockout mice lacking ER $\alpha, E R \beta$, or both ERs have shown both overlapping and distinctive roles for these receptors in estrogen action (39). The estrogen receptors undergo conformation changes during activation, forming dimers that translocate into the nucleus to regulate the activity of many genes by binding to DNA (Fig. 3). Expression of ER is very low in normal breast epithelium, and enhanced ER expression positively correlated with increased risk of breast cancer (40). 


\section{Estrogen and breast cancer}

Estrogens are necessary for the growth, development, and functioning of normal mammary glands in the breast, whereas increased levels of estrogen are associated with higher cancer risk $(9,41-43)$. As early as 1896 , George Beatson reported in Lancet, that surgical removal of the ovaries reduced tumor size and improved the outcome in premenopausal breast cancer patients (44). Epidemiological, clinical, and preclinical studies indicated that the increased risk for breast cancer was dependent on long-term hormone exposure, such as early menarche, late menopause, parity, and hormone replacement therapy $(9,10,45)$. In blood, elevated levels of estrogen were associated with the increased risk for breast cancer in both pre- and postmenopausal women $(46,47)$. Furthermore, higher concentrations of estrogen were found in breast tumor tissue compared to normal breast tissue (48-50). Approximately two-thirds of all breast cancer patients were positive for ER, and could benefit from hormone therapy, but up to $50 \%$ of these cases had either de novo resistance or developed resistance during treatment $(51,52)$. Hormone therapy or endocrine therapy, including antiestrogen, aromatase inhibitors, luteinizing hormone-releasing hormone (LH-RH) agonists, and selective estrogen receptor modulators (SERMs), interfere with the production and/or the action of estrogen and its receptors $(53,54)$. Tamoxifen has been the standard endocrine treatment in both pre- and postmenopausal breast cancer patients, although aromatase inhibitors are the preferred option in postmenopausal patients, because aromatase enzymes catalyze estrogen production in adipose tissue, liver, muscle, and adrenal glands after menopause $(55,56)$.

\section{Tamoxifen}

Tamoxifen is a selective estrogen receptor modulator (SERM), which act via its metabolites such as 4-hydroxytamoxifen (4-OHTAM) and 4-hydroxy-N-desmethyltamoxifen (endoxifen) $(57,58)$, as both an antagonist for ER $\alpha$ in breast tissue, and as an agonist in other tissues such as the endometrium and bone (59). Treatment of estrogen-dependent breast cancer with tamoxifen therefore increased the risk of developing endometrial cancer (59-61). In the breast, tamoxifen competes with estrogen for the binding site, and binds and inactivates the estrogen receptor.

This anti-hormone drug is currently used for treatment in both pre- and postmenopausal women diagnosed with early, advanced, and metastatic ER positive breast cancer, although aromatase inhibitors are more frequently used in the postmenopausal group (62). In adjuvant therapy, tamoxifen has been used to prevent the recurrence of the original tumor and the development of new tumors in the breast (63). During a period of five years, adjuvant tamoxifen therapy showed decreased recurrence rates and improved survival for both pre- and postmenopausal breast cancer patients, compared with short treatments for two years $(26,64,65)$. Recently, a better outcome has been reported for 10 years of tamoxifen treatment (25). 


\section{Fulvestrant}

Fulvestrant (faslodex) is an ER antagonist that down-regulates the ER (66). It competes with estrogen and binds to the ER with high affinity. In addition to the down-regulation of ER, binding also leads to inhibition of cellular aromatase, inhibition of the insulin growth factor (IGF) signaling pathway, and to antagonizing the activity of progestin (67).

Generally, fulvestrant has been used as a second-line treatment for postmenopausal women with advanced and metastatic ER positive breast cancer who have relapsed, or who suffer from a more progressive disease after/during first-line or adjuvant endocrine therapy (68).

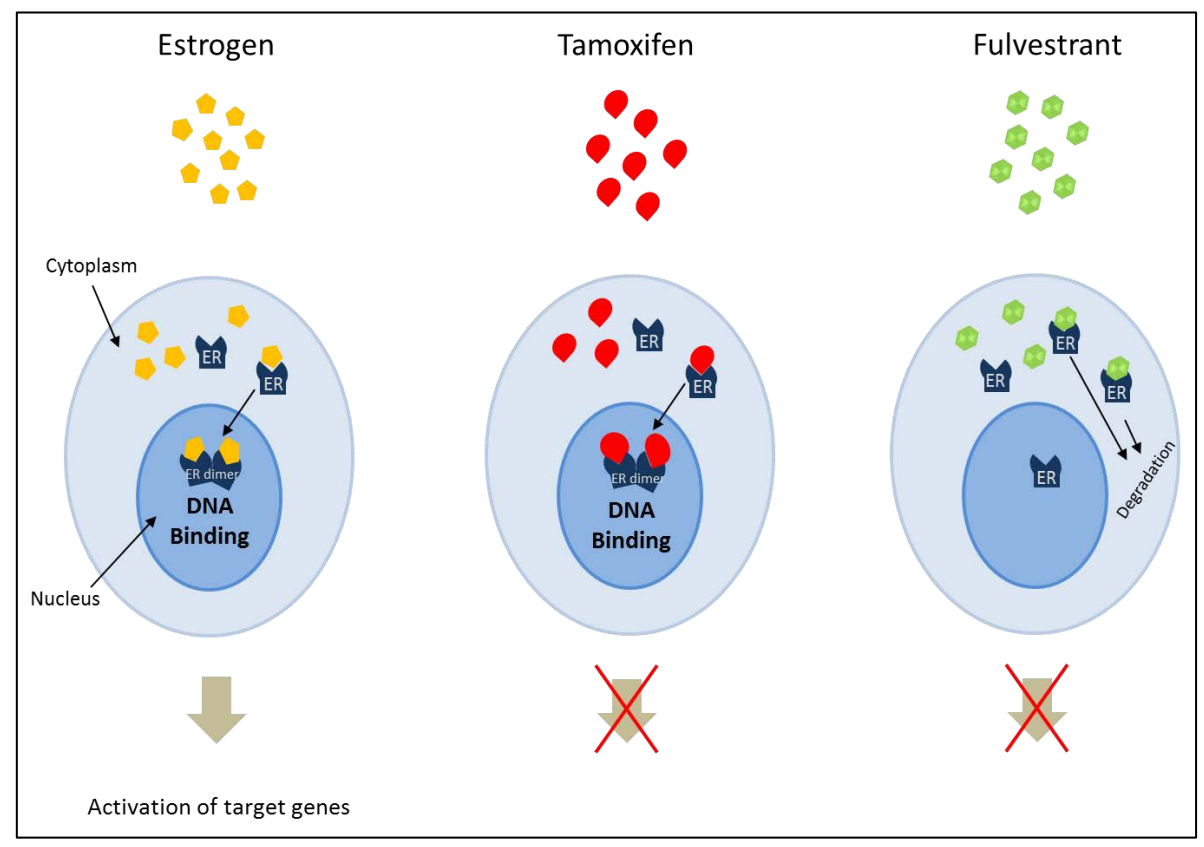

Figure 3. The action of estrogen, tamoxifen, and fulvestrant. Estrogen activates the estrogen receptor, which will go through a conformation change to form dimers that translocate into the nucleus to regulate the activity of many genes by binding to the DNA. The estrogen receptor undergoes dimerization and translocation into the nucleus but no activation upon binding to tamoxifen. Fulvestrant binds the estrogen receptor and triggers the degradation event. 


\section{Tumor microenvironment}

To fully characterize how cancer cells arise, develop, progress, and invade, it is necessary to understand how tumor cells interact with their surrounding microenvironment. This tumor microenvironment has included a number of different cell types, soluble mediators, signaling factors, and extracellular matrices which interact closely with cancer cells (69). Epithelial cells, fibroblast cells, adipocytes, and immune cells are some of the cells found in the tumor microenvironment. Their interactions with cancer cells have been thought to contribute to tumor heterogeneity, tumor development, tumor progression, metastasis, and drug resistance (70), which explains their useful role as possible prognostic markers for cancer (71). Cytokines are one of the most important components of the tumor microenvironment. They consist of interleukins, chemokines, interferons, lymphokines, and tumor necrosis factors. A broad range of cells releases these small proteins, and they affect all cells that express their receptors. They may act in an autocrine manner if they affect the producing cells, in a paracrine manner when affecting neighboring cells, or in an endocrine manner when affecting cells in distant organs.

Due to its structural and cellular composition, a unique microenvironment is present in the breast, consisting of epithelial cells, stromal cells, and immune cells surrounded by adipose tissue, known as both an hormonal and inflammatory organ (72). The breast microenvironment is continually influenced and remodeled by changes of hormonal signals during its maturation process, which include menstruation, pregnancy, and lactation. This dynamic environment makes the breast susceptible to carcinogenesis.

\section{Inflammation}

In 2011, inflammation was proposed by Hanahan and Weinberg as the seventh hallmark of cancer (1). Inflammation is the body's physiological response against dangerous stimuli such as microbial infections, injury, or chemical irritation (73). This physiological event is initiated when immune cells such as macrophages, dendritic cells, Kupffer cells, and mast cells recognize the expressed molecules by their pattern recognition receptors (PRRs) on foreign microbes or damaged tissue. This recognition event activates cells to release inflammatory factors such as growth factors, cytokines, and chemokines. The inflammatory factors act by increasing several biological processes, including the dilation of blood vessels (increases in the blood flow, which cause redness and heat) and increasing sensitivity to pain and subsequent loss of function. The inflammatory factors also increase the permeability of blood vessels, therefore plasma proteins and fluids (causing swelling) leak into the tissue. In addition, immune cells such as neutrophils can migrate towards the harmful stimuli by following the chemotactic gradient of these factors.

The body tightly regulates inflammation by eliminating and killing the harmful stimuli and then initiating the healing process (acute inflammation), however, sometimes this process becomes destructive and chronic even though the harmful stimuli are removed. This chronic inflammation has been linked to an increased risk of many cancers including breast cancer $(73,74)$. 
Epidemiological studies have shown that chronic inflammation initiates several types of cancers, and that treatment with nonsteroidal anti-inflammatory drugs (NSAIDs) reduces the incidences and the mortalities caused by certain cancers (75). Some cancers are linked to microbial infections, such as infection with Helicobacter pylori, which is associated with gastric cancer and gastric mucosal lymphoma. In other cases, a relation to autoimmune diseases has been found, such as the association between inflammatory bowel disease and colon cancer $(76,77)$. In addition, the presence of inflammatory cells, chemokines, and cytokines has been well established in the microenvironment of most tumors $(74,78-80)$.

\section{Inflammation and breast cancer}

Infiltration of leukocytes has been reported in most cancers including breast cancer. This cellular infiltration includes several immune cells such as lymphoid cells, macrophages, granulocytes, mast cells, dendritic cells, and natural killer cells. Several studies have reported that approximately $50 \%$ of the breast tumor mass comprised of macrophages (8183). Macrophages have also been implicated in promoting tumor initiation, progression, invasion, and metastases $(84,85)$. Importantly, targeting tumor-associated macrophages using a vaccine-based approach has reduced tumor growth, tumor angiogenesis, and metastasis in many cancers, including breast cancer $(86,87)$.

In addition to the immune cells, the expression of many inflammatory mediators, such as cytokines, chemokines, and enzymes, has an important function in carcinogenesis. Cytokines, expressed by both tumor and stroma cells, are thought to have dual functions in malignances (88). They can be involved in almost all aspects of tumor biology, including initiation, tumor growth, invasion, and metastasis through proinflammatory cytokines, but can also trigger the immune effector mechanisms and inhibit cancer proliferation and invasion through the anti-inflammatory cytokines.

A variety of cytokines has been detected in breast cancer, including tumor necrosis factor- $\alpha$ (TNF- $\alpha$ ), interleukin-1 (IL-1), IL-2, IL-6, IL-10, and interferon (IFN)- $\alpha, \beta$ and $\gamma$ (89-91). IL-1 is one of the most potent proinflammatory cytokines, implicated in the induction of expression of numerous cytokines, including IL-8, vascular endothelial growth factor (VEGF), and IL-6 (92). It may therefore be involved in angiogenesis, tumor proliferation, and tumor invasion (92). 


\section{The interleukin-1 family}

The IL-1 family is one of the central regulators of immune and inflammatory responses. It is comprised of both activators and suppressors of inflammation at both receptor and nuclear levels (93). IL-1s are involved in carcinogenesis, angiogenesis, and invasion, but in contrast, they also activate immune mechanisms, which inhibit tumor growth (94). Eleven proinflammatory cytokines belong to this family, but the most studied members are IL- $1 \alpha$, IL-1 $\beta$, and the IL-1 receptor antagonist (IL-1Ra) (95).

As previously mentioned, the release of IL-1 into the tumor microenvironment can increase the production of several cytokines such as IL-6, the pro-angiogenic factors VEGF and IL-8, adhesion molecules and several transcriptional factors including nuclear factor-KB (NF-KB), AP-1, JNK, and p38 MAPK thereby also contributing to breast carcinogenesis (96). All cytokines function by binding to their specific membrane receptors expressed on the surface of nearly all cell types. IL-1s bind to two receptors called the IL-1 receptor type I (IL1R1) and IL-1 receptor type II (IL-1RII), both belonging to the IL-1 receptor cytokine family. In addition to IL-1RI and IL-1RII, this cytokine family includes eight other members regulating the activity of IL-1 ligands (97). The receptors in the IL-1 receptor cytokine family generally consist of one cytoplasmic Toll/IL-1 receptor domain (TIR) and three extracellular immunoglobulin domains (98). IL-1 $\alpha$ or IL-1 $\beta$ binding to IL-1RI leads to an activation event, while binding to IL-1RII, a decoy receptor, results in the neutralization of IL-1 effects, because the receptor lacks the transmembrane domain that transmits the signal through the membrane. Upon the activation of IL-1RI by IL-1 $\alpha$ or IL-1 $\beta$, a third protein, IL-1 receptor accessory protein (IL-1RACP), is recruited to form the receptor complex, which activates several signaling pathways in the cells. The second molecule that negatively regulates the signaling pathways of IL-1 is the IL-1 receptor antagonist (IL-1Ra), which binds to IL-1R1s, but prevents binding to the IL-1 receptor accessory protein (IL-1RAcP), and thereby inhibits the activation signal (Fig. 4) (99).

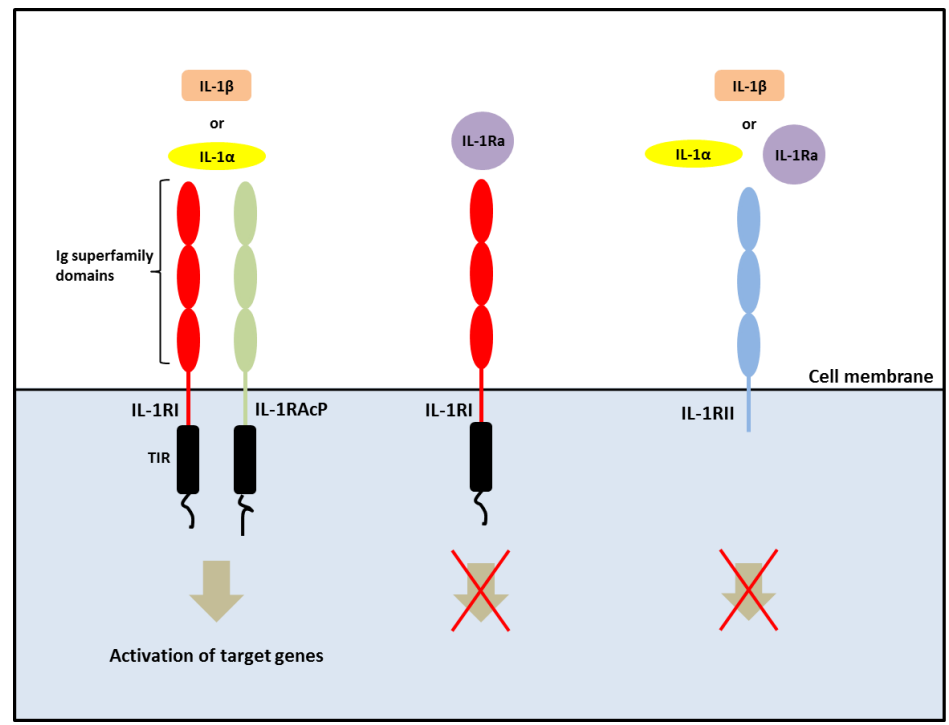

Figure 4. A schematic picture illustrating the interaction between IL1 cytokine family (IL-1 $\alpha$, IL-16 and IL-1Ra) and IL-1 receptor family (IL$1 R I, \quad I L-1 R I I$, and the accessory protein (IL1RACP)). 


\section{IL-1 $\alpha, I L-16$, and IL-1Ra}

IL- $1 \alpha$ and IL-1 $\beta$ are the most well-known proinflammatory cytokines in the IL- 1 family. These cytokines are produced not only by several immune cells, including macrophages and monocytes, but also by epithelial cells and endothelial cells, which suggests that they can also be produced by cancer cells themselves $(93,100)$. Both IL-1 $\alpha$ and IL-1 $\beta$ are synthesized as $31 \mathrm{kDa}$ precursor proteins and translated in the cytosol. The mature form of IL-1 $\alpha$ is generated through the proteolytic cleavage by the $\mathrm{Ca}^{2+}$-activated cysteine protease calpain, while mature IL-1 $\beta$ is activated by the enzyme caspase- 1 , which is included in the inflammasome $(93,101)$. In contrast to pro-IL-1 $\beta$, the IL-1 $\alpha$ precursor (Pro-IL-1 $\alpha$ ) is biologically active and has a nuclear localization sequence (NLS) at amino acids 79-86 for translocation from the cytoplasm to the nucleus (102).

Mature IL-1 $\alpha$ and IL-1 $\beta$ bind and activate the IL-1 receptor type I (IL-1RI) on target cells, by triggering the recruitment and binding of IL-1 receptor accessory protein (IL-1RAcP). This binding activates several signaling pathways, including the activation of NF-KB and mitogen activated protein kinase (MAPK) pathways (96).

IL-1Ra is, a natural inhibitor of IL-1 signaling, produced by many different cells such as immune cells, epithelial cells, and adipocytes. It inhibits the function of IL-1 $\alpha$ and IL-1 $\beta$, by binding IL-1RI and preventing the signal transduction. Thus, IL-1Ra levels have been studied in many diseases such as autoimmune diseases, metabolic diseases, sepsis, and cancer (103). Recombinant IL-1Ra, also named anakinra, has been successively used as a therapeutic agent in rheumatoid arthritis and in clinical trials for other diseases such as sepsis and graft versus host disease (104). Furthermore, it has been proposed for treatment of type 2 diabetes and cancer $(105,106)$.

The role of the IL-1 cytokine family in cancer has been demonstrated in vivo in IL-1 knockout mice, where it reduced both tumor growth and angiogenesis (94). The expression of IL-1 $\alpha$, IL-1 $\beta$, and IL-1Ra has been well-characterized in the circulation of breast cancer patients, breast cancer homogenates, and breast cancer cell lines. For example, elevated levels of IL$1 \beta$ have been correlated with higher tumor grade and more aggressive and invasive breast cancers (107). Furthermore, the activation of IL-1 receptors on breast cancer cells via autocrine and/or paracrine mechanisms induced the secretion of other cytokines, chemokines, adhesion molecules, and receptors, which contributed to tumor cell growth, angiogenesis, and tumor invasion (108). Normal human mammary epithelial cells and breast cancer cells both expressed IL-1RI and IL-1RII (109). 


\section{Adipokines}

In the breast, the adipocytes are the most abundant cell type surrounding epithelial cells and mammary cancer cells. Besides their energy storage and regulation functions, these active endocrine cells produce and secrete several bioactive molecules called adipokines $(110,111)$. These adipokines include hormones, growth factors, angiogenic factors, and proinflammatory cytokines (110-112). Generally, adipokines have local biological effects, but they are also found in the circulation where they influence multiple physiological and pathological processes. Adipokines refer often to leptin and adiponectin, but other factors such as resistin, visfatin, apelin, omentin, IL-6, and TNF- $\alpha$ are also produced by adipocytes $(113,114)$.

\section{Leptin and the leptin receptor}

Leptin is a $16 \mathrm{kDa}$ protein coded by the obese $(\mathrm{Ob})$ gene, and mainly secreted by adipocytes. It shares structural homology with growth hormone, leukemia inhibitory factor, IL-6 and granulocyte colony stimulating factor (G-CSF) (115). Leptin plays an important role in several biological processes including food intake, body weight, energy balance, fetal development, angiogenesis, sex mutation, and immune responses (116-123). Leptin exerts its function by binding to its membrane-associated receptor, the leptin receptor (Ob-R). This receptor exists in six isoforms produced by alternative mRNA splicing, but only the longest isoform $(\mathrm{Ob}-\mathrm{Rb})$ has the full signaling capacity $(124,125)$. The Ob-R isoforms differ in the length of their intracellular domains, but they share identical transmembrane and extracellular domains, consisting of two homologous cytokine receptor domains ( $\mathrm{CRH} 1$ and $\mathrm{CRH} 2$ ), a conserved immunoglobulin (Ig) domain, and two fibronectin type 3 domains (126). Leptin binding to Ob-R triggers conformational changes and promotes the dimerization of Ob-R, which initiates the activation of several downstream signaling pathways such as the Janus tyrosine kinase 2 (JAK2)/signal transducer and activator of transcription 3 (STAT3), MAPK, and the phosphatidylinositol 3-kinase-protein kinase B (PI3K-AKT) pathways, which all have different physiological consequences $(125,127)$.

In breast cancer, leptin has been shown to have a role in increasing the proliferation of several breast cancer cell lines, in increasing expression of aromatase, and in enhancing angiogenesis by increasing the expression of VEGF (128-130). Circulating levels of leptin have been shown to increase the risk of breast cancer in postmenopausal women (131, 132), but not in premenopausal women (133). Both leptin and Ob-R are overexpressed in human breast cancer tumors compared to normal breast tissue, and this expression is associated with distant metastasis $(134,135)$. Furthermore, in vivo studies of leptin and Ob$\mathrm{R}$ deficient animal models showed that leptin and its receptor were involved in the development of breast cancer $(136,137)$.

\section{Adiponectin and the adiponectin receptors}

Adiponectin is the most abundant adipokine produced by adipocytes. It has a significant role in a number of metabolic processes including glucose regulation, fatty acid oxidation, and vascular regulation (138). In the plasma, adiponectin exists as multimers in two adiponectin forms, the globular form of adiponectin and the full-length form of adiponectin. Like all other cytokines, adiponectin functions through interaction with membrane-associated 
receptors, in this case, mainly through two G-protein-coupled receptors named the adiponectin receptor 1 (AdipoR1) and the adiponectin receptor 2 (AdipoR2) (139). However, a third receptor, $\mathrm{T}$-cadherin ( $\mathrm{CDH} 13)$, has been reported to be a receptor for higher-order multimers of adiponectin (140). Each of these receptors has a specific tissue distribution and different affinities to different adiponectin forms (139). Adiponectin binding to either AdipoR1 or AdipoR2 promotes homo- or heterodimerization (141) to activate several intracellular pathways such as adenosine monophosphate-activated protein kinase (AMPK), peroxisome proliferator-activated receptor- $\alpha$ (PPAR $\alpha$ ), and JAK-STAT (142-145).

Adiponectin plays a key role in carcinogenesis. Several studies have shown the negative effect of adiponectin on the proliferation of several cancer cell lines $(144,146)$. Epidemiological studies, using serum adiponectin level as a measure of tissue exposure, suggested that adiponectin was a protective factor against breast cancer (147-151). In vitro studies have demonstrated that adiponectin induced apoptosis and inhibited migration and invasion of breast cancer cells $(152,153)$. Furthermore, adiponectin suppressed the growth of the cancer in experimental breast cancer xenografts (146). Both AdipoR1 and AdipoR2 were detected in breast cancer tissue (154-156) and in breast cancer cell lines (157). Knockdown of AdipoR1 by siRNA stopped the inhibitory effects of adiponectin on breast cancer (158). However, T-cadherin was not expressed in tumors, but the introduction of this receptor decreased the malignant growth of breast cancer (159) .

\section{Leptin/adiponectin ratio}

As previously mentioned, an opposite relationship has been described for leptin and adiponectin in many disease conditions such as breast cancer (160). For example, adiponectin antagonized leptin activities in several breast cancer cell lines and in animal models $(161,162)$. Thus, several investigators suggested that the ratio of these two

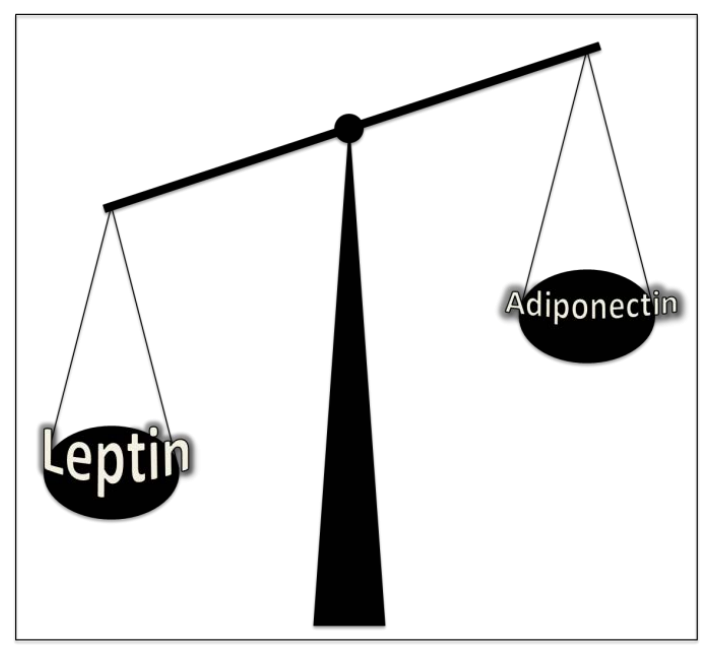
adipokines, rather than their individual concentrations, should be measured and used as a clinical marker $(160,163)$. Consistent with this suggestion, many studies have shown an association between high leptin:adiponectin ratios and increased risk of breast cancer (164, 165).

Figure 5. A graphic picture elucidating the leptin:adiponectin ratio in breast cancer. 


\section{Angiogenesis}

A network of blood vessels maintains all cell and tissue homeostasis, by furnishing nutrition and oxygen and removing toxins and waste products produced in the body. Vasculogenesis promotes the first primitive vascular network during embryogenesis, while angiogenesis is the physiological process of creating new capillary blood vessels from the existing vasculature. Angiogenesis is important both in healthy and diseased tissue. Under normal physiological condition, it is necessary for embryonic development, in the repair of wounded tissue, and in the formation of the placenta during pregnancy. Several "on" and "off" molecules strictly regulate angiogenesis. The body initiates the formation of new vessels by increasing the amount of "on" switchers, also called angiogenesis-stimulating growth factors, compared to the amount of "off" molecules, called angiogenesis inhibitors. To prevent angiogenesis, inhibitors are favored over growth factors. When this balance is disturbed, the body loses its normal control, and pathological angiogenesis occurs. This pathological angiogenesis can either be excessive, such as in cancer, in rheumatoid arthritis, and in psoriasis; pathological angiogenesis can also be insufficient and lead to tissue death, such as in coronary artery disease, stroke, or in a chronic wound $(166,167)$

Angiogenesis is very important in all steps of cancer development, including its initiation, progression, invasion, and metastasis $(168,169)$. The newly-formed blood vessels carry the nutrients necessary to feed and sustain the tumor, while at the same time allowing the cancer cells to leave their original site and spread to distant organs (170). According to autopsy reports, $15-30 \%$ of all women have been found to have in situ breast cancer, but only $1 \%$ were diagnosed with breast cancer among women in the same age group (171). A potential explanation, based upon, clinical and experimental studies, involves the possibility that human tumors remain as dormant tumors in situ for a long periods of time before becoming clinically relevant tumors when angiogenesis occurs $(172,173)$.

There are many well-known endogenous angiogenesis-stimulating growth factors, including interleukin-8 (IL-8), leptin, tumor necrosis factor- $\alpha$ (TNF- $\alpha$ ), granulocyte colony stimulating factor (G-CSF), and vascular endothelial growth factor (VEGF) (174). VEGF is thought to be the major stimulator of angiogenesis. Endostatin, angiostatin, tumstatin, thrombospondin-1 (TSP-1) and -2, and transforming growth factor-beta (TGF-b) are additional inhibitors of angiogenesis $(175,176)$.

\section{Vascular endothelial growth factor (VEGF)}

VEGF is a pro-angiogenic and vasculogenic growth factor involved in many physiological functions such as bone formation, hematopoiesis, and wound healing (177, 178). Furthermore, its association with tumor growth and vascular disease is well documented $(166,179,180)$. VEGF belongs to the platelet-derived growth factor family, which in addition to VEGF (also known as VEGF-A), includes VEGF-B, VEGF-C, VEGF-D, VEGF-E, VEGF-F, and placental growth Factor (PIGF) (181).

Elevated levels of VEGF are found in many cancer types, including breast cancer $(182,183)$, but because most VEGF in the serum is secreted by activated platelets $(184,185)$, the interpretation of these studies has been very challenging. However, the use of plasma VEGF 
levels is recommended for the study of circulating VEGF (184). The overexpression of VEGF in many solid tumors has been correlated with the progression, invasion, and metastasis of the tumors (179). In breast cancer, high tumor levels of VEGF are associated with poor prognosis and worse outcome in both node-positive and node-negative patients $(186,187)$. The in situ levels of extracellular VEGF were significantly higher in human breast tumors compared to normal breast tissue (188). Moreover, extracellular VEGF levels were increased in human breast tissue in vivo during the luteal phase of the menstrual cycle (189). In addition, both VEGF and VEGFRs were expressed in breast cancer cell lines (190).

\section{Nutrition and breast cancer}

Migration studies, involving women who moved from countries with the low incidence rates to countries with high incidence rates, have revealed a significant contribution of environmental factors in increasing the risk of breast cancer $(191,192)$. In the Western countries, with high fat, meat-based, and low fiber diets, the incidence rates of breast cancer are the highest in the world. Asian countries, with a more plant-based diet, have shown significantly lower incidence rates (193). The plant-based diet includes fruits, vegetables, whole grains, berries, and beans, which contain high levels of phytoestrogens, substances that have a structure similar to estrogens and can bind weakly to ERs. The phytoestrogens have agonistic or antagonistic effects on ER activation, depending on the structure, metabolism and concentration in relation to the endogenous estrogen.

There three major classes of phytoestrogens are isoflavones, lignans and coumestans. Soybeans, soy products, and other legumes are high in isoflavones, while vegetables such as broccoli and sprouts are high in coumestans. Lignans are found in seeds, berries, fruit, vegetables, and nuts, and are the main source of phytoestrogens in the Western diet (194, 195). The highest amounts of lignans are found in flaxseed $(195,196)$. Flaxseed contains secoisolariciresinol diglycoside (SDG), which is converted by the colonic bacteria to enterodiol and then to enterolactone, which are the two main mammalian lignans (197, 198). Overall, conflicting results have been reported regarding the association between dietary intake of lignans and breast cancer. Some prospective cohort studies found no association (199, 200), while other studies reported that consumption of lignan phytoestrogens were associated with a decreased risk of breast cancer $(201,202)$. SDG has also been reported to inhibit the formation of mammary breast tumors in rats (203). Conflicting results have been reported regarding the connection between eating soy products and breast cancer risk. No connection has been found between coumestans and breast cancer risk $(8,204,205)$. 


\section{Aims of this thesis}

Paper I and Paper II:

- Determine the presence of IL-1 cytokines (Paper I) and adipokines (Paper II) in the extracellular space of breast tissue in vivo

- Determine whether these immune modulators are up-regulated or down-regulated in breast cancer tumors in vivo

- Investigate the effects of sex steroids and nutrition on IL-1 levels (Paper I) and on adipokine levels (Paper II) in normal breast tissue in vivo

Paper III:

- Investigate if there are any relationships between IL-1, leptin, adiponectin, and/or VEGF in the extracellular space of normal breast tissue in vivo

- Determine the role of estradiol in the regulation of these factors using co-cultures of human adipocytes and estrogen receptor positive breast cancer cells 


\section{Comments on methods}

In this section, a brief description, with comments, for each method is presented to provide a better understanding of the methodological procedures. Further details about the different experimental protocols can be found in the material and method sections of each paper.

\section{Cancer cell lines}

Cell lines are widely used by many biochemical studies, especially in cancer research (206). The abilities of cell lines to obtain reproducible results, to provide unlimited sources of material, and to avoid interference problems related with primary cells, make them very important tools in cancer research. In addition, the use of cell lines does not require ethical permission. However, there are some limiting factors when using cell lines, such as genomic instability, which may develop when cells have been used for a long time. Also, cross contamination between cell lines and mycoplasma infections needs to be regularly controlled (207-209).

In this thesis, the MCF7 cell line is used. MCF7 is a breast adenocarcinoma cell line established in 1973 at the Michigan Cancer Foundation from a pleural effusion removed from a women with metastatic breast cancer (210). This cell line is suitable for the experiments with hormone treatments because it expresses both the estrogen receptor and the progesterone receptor as in a manner similar to the majority of breast cancer tumors (211). In addition, this cell line has the ability to maintain its hormone sensitivity over a long period of cell culture (90). All the experiments described in this thesis were carried out with MCF7 cells, obtained from the American Type Culture Collection (ATCC). The cells were mycoplasma free and the risk for cross contamination and genomic instability were avoided by always starting with a frozen MCF7 stock from an early passage, and by limiting the amount of passages during each experiment.

\section{Human primary cells}

Primary cells are a superior model compared to cell lines, because they closely resemble the physiological state of in vivo cells. They are generally used in many studies such as cell differentiation and combination culture (co-culture) studies. Although primary cells provide more biologically relevant material, several aspects need to be considered when choosing them for studies. Generally, primary cells are heterogeneous, not reproducible, and are not as well characterized as cell lines. Also, because they are derived from different individuals, their behavior in culture may differ, even when they are identically treated. Other characteristics such as a limited amount and very short lifespan are also typical for these cells (212).

In this thesis, primary mature adipocyte cells were isolated from the subcutaneous (s.c.) abdominal fat tissue obtained during elective surgery from women at the University Hospital in Linköping. We choose to use primary mature adipocytes instead of in vitro differentiated preadipocytes because some of substances used to differentiate the preadipocytes may have an impact on the secreted adipokines. As an example, dexamethasone may inhibit the release of adiponectin $(213,214)$. 
The isolated adipocytes were immediately co-cultured with preseeded breast cancer cell lines to avoid the characteristic changes, which may occur during subculture. Due to the fragility, diversity in size, and the difficulty in distinguishing adipocytes from pure lipid droplets, the measurement of mature adipocytes numbers are very problematic. Therefore, equal volumes of adipocyte cell suspension were added to each preseeded well containing a constant number of MCF7 cells. As control, breast cancer cell lines and adipocytes were also cultured alone in culture media used in the co-culture experiments (Fig. 6). In culture, mature adipocytes float to the top of the medium in clumps, which will restrict their proper access to the nutrients in the medium. This will force the majority of adipocyte to go through cell lysis within 72 hours (215). Due to the restricted lifespan of mature adipocytes, the co-culture was only carried out for two days. All the culture combinations were performed on cells isolated from a single volunteer, while the repeated experiments were carried out with cells from another volunteer but under the same experimental conditions.

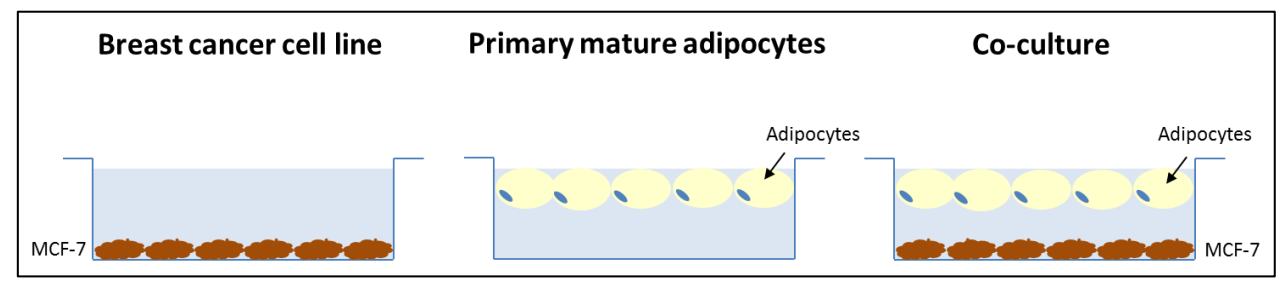

Figure 6. A schematic picture for the co-culture study. Breast cancer cell lines and adipocytes cultured for 2 days alone in co-culture media to function as controls. Fresh isolated primary mature adipocyte cells were co-cultured with preseeded breast cancer cell lines for 2 days in the presence or absence of different treatment conditions such as estradiol. ELISA was used to analyze the supernatant.

\section{Human tissue in culture}

Tissue culture technology has been used since 1885, when Wilhelm Roux performed the first tissue culture experiment by keeping a section from an embryonic chicken in solution for days $(216,217)$. The small tissue pieces used with this technique contained all the cell types in the specific tissue, and were left in their surrounding extracellular matrix, providing a three-dimensional tissue model without the use of an artificial matrix. Therefore, in vitro culture of these pieces mimicked the in vivo environment of the studied tissue (218). Individual differences may occur in this model when using tissue from different donors. In addition, the percentage of each cell type represented in the tissue was not identical in all tissue biopsies, which may affect the treatment results. To overcome this problem, several biopsies from the same donor were treated with in the same manner.

In this thesis, a biopsy punch was used to cut $8 \mathrm{~mm}$ biopsies of normal human breast tissue, obtained from premenopausal women undergoing routine reduction mammoplasty. The small biopsies contained several types of breast cells, such as epithelium cells, stromal cells, and adipose tissue. The biopsies were placed in a 12-well plate and cultured for seven days in the presence or absence of different hormone/anti-hormone conditions to evaluate their effects. The treatment was carried out for seven days because Garvin et al (2006) reported preserved morphology and structural integrity in breast tissue cultured for one week (218). All sex steroids or anti-estrogen drugs were used in physiologically relevant concentrations 
and because the half-life of estradiol is approximately 13-17 hours, the media were changed every day. After the treatment period, the medium and the biopsies, were analyzed by ELISA and immunohistochemistry, respectively (Fig. 7). All treatments involved tissue from one

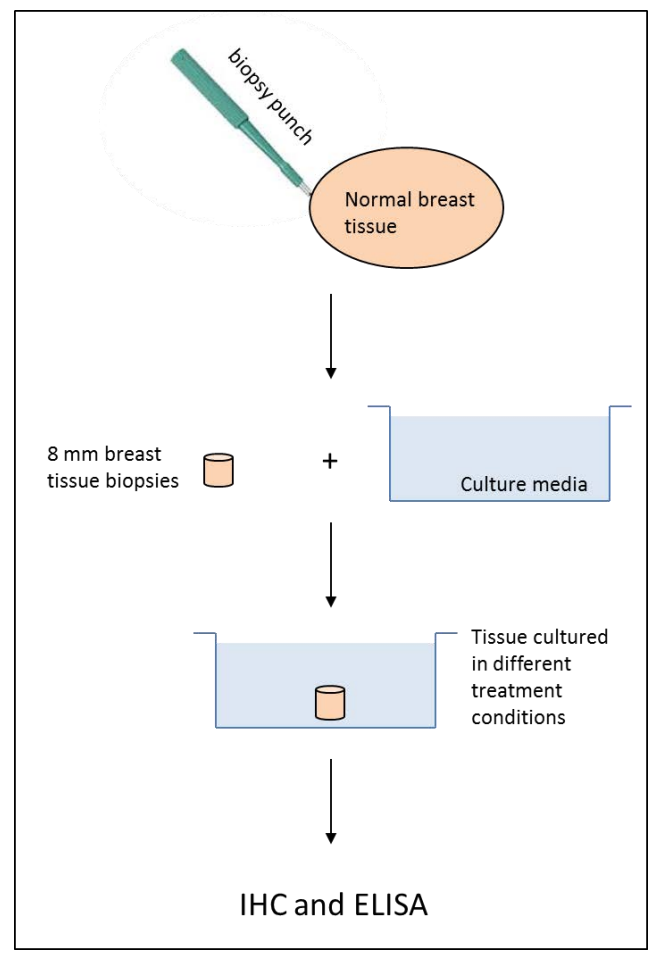

single donor, while the repeated experiments were performed on tissues from another donor, to overcome the problem with intraindividual differences, which may have occurred in the biological response studies.

Figure 7. A schematic picture for the tissue culture technique used in this thesis. A biopsy punch is used to produce small tissue biopsies from normal breast tissue obtain from premenopausal women undergoing routine reduction mammoplasty. The biopsies are placed in a 12-well plate and culture in different treatment conditions for seven days. ELISA and immunohistochemistry analyze the medium and the biopsies respectively, after the hormone treatment.

\section{Microdialysis}

Since the early 1960s, microdialysis has been used to study brain biochemistry in rodents, but the use of microdialysis in humans has gradually increased, specifically for monitoring free unbound drug concentrations in diverse tissues (219-222). Microdialysis is an in vivo sampling technique used for constant collection of small biochemical molecules from the extracellular fluid of different tissues or organs (219). By mimicking the function of a capillary blood vessel, the microdialysis catheter (called a probe in animals) with its semipermeable membrane, is able to either collect endogenous molecules, or disperse exogenous compounds (retrodialysis) in any tissue of interest. The microdialysis catheter is inserted into a specific tissue and connected to a pump, so that the catheter is continuously perfused with an aqueous solution (perfusate) with a similar ionic content as the extracellular fluid. The perfusate will flow through the inner tube, passing by the semipermeable membrane where the extracellular molecule will enter the perfusate by passive diffusion, and then continue out through the outgoing tubing system to be collected in plastic microvials (Fig. 8) (220). 


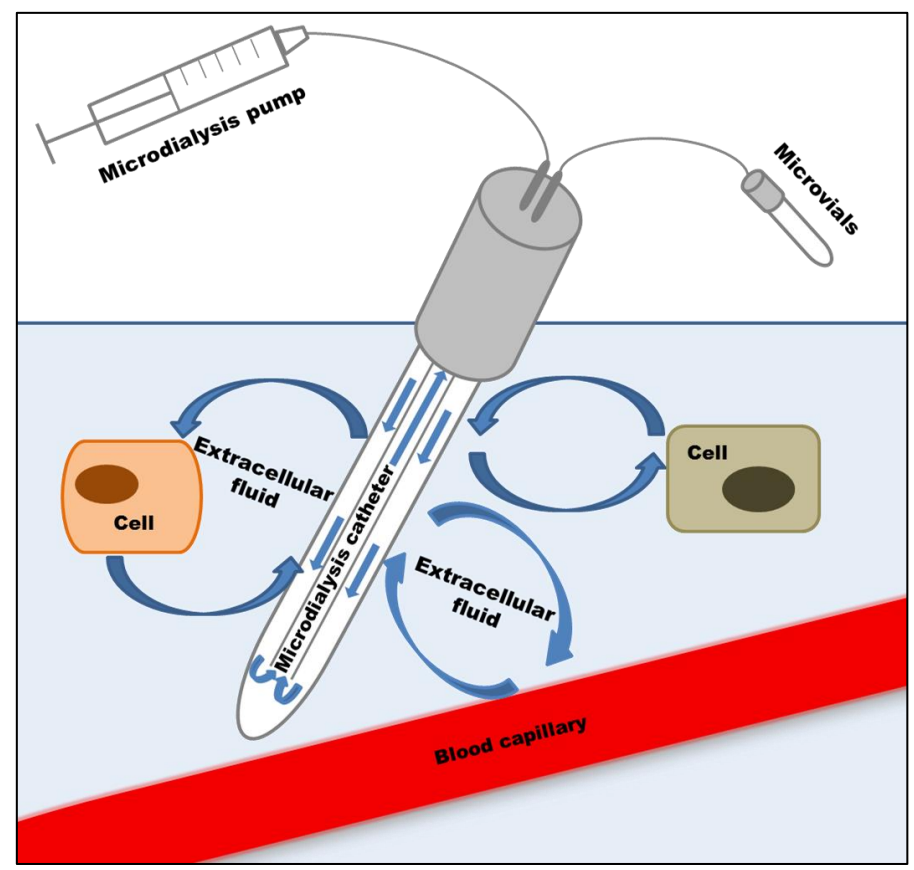

Figure 8. A schematic picture for the microdialysis technique. The microdalysis catheter mimics the function of a capillary blood vessel, allowing the collection of various biochemical substances from the extracellular fluid. The collected dialysate passes through the semipermeable membrane by passive diffusion, to be carried out by a continuous flow of the perfusion fluid through the outgoing tubing system to a plastic microvial.

Due to passive diffusion, which is a spontaneous process where molecules will transfer between two fluids to establish concentration equivalence, small endogenous molecules such as cytokines, adipokines, neurotransmitters, and hormones can cross the semipermeable membrane and be collected at certain time intervals from the extracellular milieu. Several factors will contribute to the extraction efficiency of each collected analyte in this system. These factors include the length and the molecular weight cut-off of the semipermeable membrane, the flow rate of the perfusate, the perfusate composition, and the ability of the analyte to freely enter the membrane. In addition, in vivo factors such as temperature, blood flow, and intestinal pressure can also affects the recovery of different analytes $(219,220)$.

Even though microdialysis is an excellent in vivo sampling technique, there are some potential problems that should be mentioned. Air bubbles may get trapped in the system and block the semipermeable membrane pores, resulting in a lower recovery rate. Another potential problem involves implantation traumas caused by the microdialysis catheter insertion. The entire tubing system is perfused, with perfusion of fluid for a short period of time (45-60 minutes), after the insertion of the microdialysis catheter and prior to the start of the collection. This short perfusion will eliminate any acute tissue damages and immune responses associated with the catheter insertion, while at the same time it can check the system for the presence of any air bubbles.

Compared to other in vivo perfusion techniques, such as microinjection or push-pull perfusion, the microdialysis with its semipermeable membrane is the only technique that provides a physical barrier to protect the tissue from artificial fluid pressure and infectious 
agents, such as bacteria. The small probe used in microdialysis facilitates specific sampling from a small structure, which at the same time can be a limitation if the structure to be studied is a large tissue, such as a whole organ. Another limitation of microdialysis is the limited time resolution, where a value for a well-defined period of time is provided, rather than real-time data as in voltammetry. However, the sampling substances using microdialysis are not limited to electroactive substances, as is the voltammetry technique, but also include all extracellular substances with molecular weights less than the pore size of the semipermeable membrane.

Dr. C. Dabrosin at Linköping's University has introduced and improved the microdialysis technique to investigate the in vivo biology of the human breast, both in healthy and cancerous conditions $(188,189,223-226)$. In this thesis, the microdialysis technique was performed in both human subjects and in animal models, to measure the extracellular levels of the IL-1 cytokines, adipokines, hormones, and VEGF in normal and cancerous tissues.

Membranes with a pore size of $100 \mathrm{kDa}$ were used for all studies. Cells and bacteria were too large to pass through the membrane, while all molecules we studied had a molecular weight less than $100 \mathrm{kDa}$, making them freely passable through the membrane. A 60\% Voluven perfusate solution containing hydroxyethyl was used as synthetic colloid to avoid ultrafiltration and leakage of the perfusate into the tissue $(227,228)$. The collected analytes were constantly replaced by the perfusate inside the microdialysis catheter, which allowed in vivo sampling without any loss of fluid. The perfusion rate was set at $0.5 \mu \mathrm{L} /$ minute for the human studies and $0.6 \mu \mathrm{L} /$ minute for the animal studies. For the human studies, we used a $20 \mathrm{~mm}$ membrane for normal breast tissue and a $10 \mathrm{~mm}$ membrane for breast cancer patients investigated before tumor surgery, while the membrane length was only 4 $\mathrm{mm}$ in the animal studies.

The recovery, a measurement used to describe the relationship between the analyte amount in the dialysate and in the peripheral tissue, will never reach $100 \%$, but it could be estimated by performing in vitro experiments using a standard solution of the studied analyte. However the true recovery for a certain analyte cannot be extrapolated from the estimated in vitro recovery because analytes behave differently in the tissue compared to a solution. Thus, all the microdialysis values were presented as raw original data. Furthermore, these values were used to compare the amounts of each analyte between groups, and were not been used to estimate the absolute levels of the analytes in specific tissues.

\section{Human subjects}

Human subjects are the ultimate model for research studies because they provide the best knowledge about the "natural course" of the disease. However, there are several issues that need to be considered. Ethical approval needs to be obtained before the start of the project. All participants must be properly informed about the risks and benefits of the study, and they must give their informed consent. The privacy and the safety of the participants must be protected, and the confidentiality of the data obtained must be maintained. In addition, the general population should to be represented in the participant group in terms of age, 
gender, socioeconomic status, and physical activity. Other issues with human subjects involve the complexities of their physiological and behavioral parameters. In contrast to human subjects, animal models offer simple biological systems and are easier to control in their "laboratory environment".

In this thesis, microdialysis was used to sample the extracellular levels of IL-1 cytokine, adipokines, hormones, and VEGF in both normal breast tissues and in breast cancer tissues. The Linköping University Hospital ethics committee approved this human study, and all participants gave their informed consent. None of the participants was treated with antibiotics or sex steroids for at least three months prior to the microdialysis studies, to eliminate interference by chemical derivatives of estradiol that might be present from these treatments.

The human subjects were divided in two groups. Women in the first group were investigated using their normal breast tissue, while women in the second group were investigated using breast cancer tissue. Women in the group with normal breast tissue were further divided into four subgroups. The first three subgroups consisted of premenopausal women, 20-32-years-old, with a history of regular menstrual cycles (cycle length, 27-34 days) while women in the last subgroup were postmenopausal women, 58-78-years-old, who were investigated before and six weeks after adjuvant treatment with tamoxifen (see Fig. 9 for more detailed group divisions).

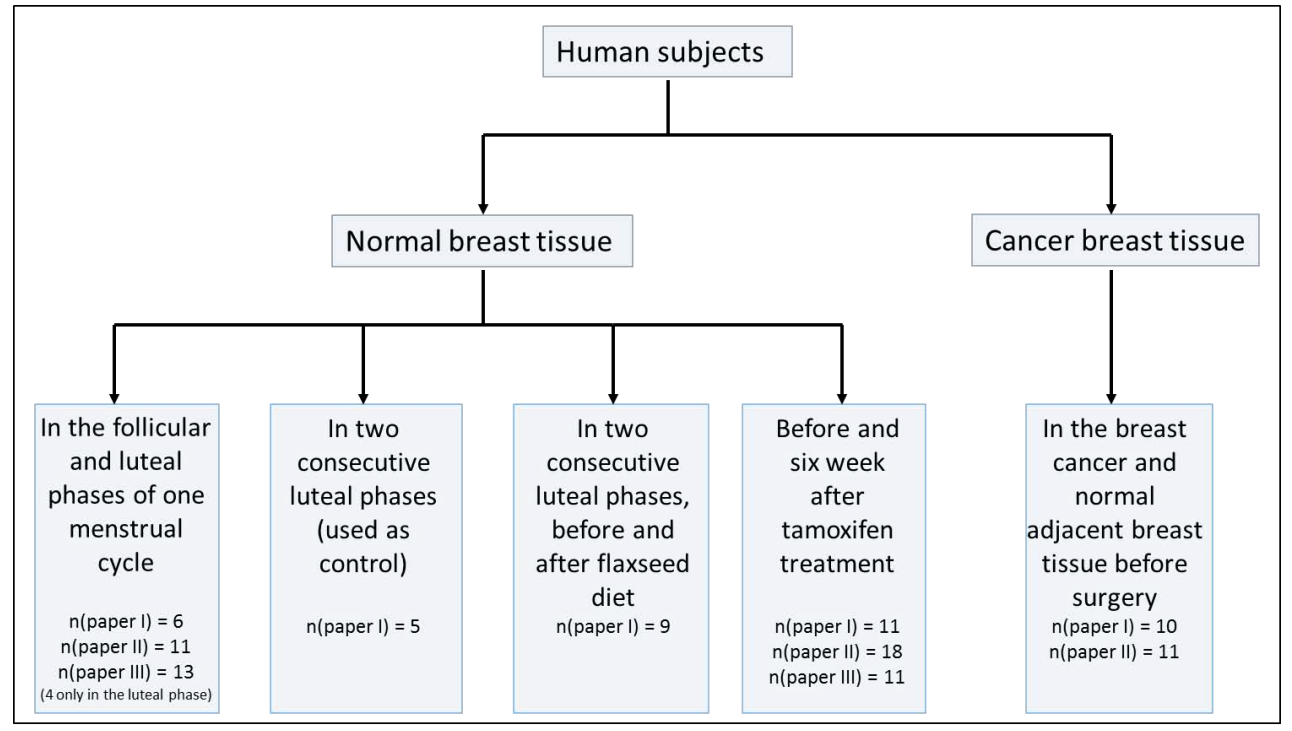

Figure 9. The group division of the human subjects.

The proteins in the normal breast tissue group were collected and analyzed for physiological changes of hormone levels in the follicular and the luteal phase during a single menstrual cycle. In the group that was investigated before and after diet modification with flaxseed, both microdialysis studies were performed during the consecutive luteal phase. We also included a control group with women studied during two consecutive luteal phases without 
any diet modifications. The group with tamoxifen exposure included postmenopausal women studied before and after six weeks receiving tamoxifen as adjuvant treatment. In healthy women, the microdialysis catheter was always inserted in their left breast, and one microdialysis catheter was inserted in the abdominal s.c. fat, as an internal control. In cancer patients receiving tamoxifen as adjuvant therapy, one catheter was inserted in the unaffected breast and one catheter was inserted in the abdominal s.c. fat.

All women in the breast cancer tissue group were postmenopausal women, and were 58-78 years of age. Their breast cancer and normal adjacent breast tissues were investigated before surgery. One catheter was inserted intratumorally in the cancer tissue, and one catheter was inserted in the normal adjacent tissue. After surgery, all the removed tumors were analyzed with immunohistochemistry for estrogen (ER) and progesterone (PR) receptors. Tumor histology, tumor size, and Nottingham Histological Grade (NHG) according to the Elston Ellis scoring system were also determined for each patient at the Department of Pathology and Cytology, University Hospital of Linköping. The characteristics of patients studied using intratumoral microdialysis are shown in table 1 (Paper I) and table 1 (Paper II).

\section{Animal models}

In several research fields, especially in basic biomedical research and drug development, animal models are use because of their biological similarities to humans. Animals offer a simple live model with a short life cycle that is easy to study. The ability to control the environment, such as the diet, temperature, and light, makes it easier to work with animal models. In addition, animals share several diseases with humans, making them suitable for studying different disease patterns and testing/developing new therapeutic drugs. Their potential for testing therapeutic drugs makes them useful for determining the beneficial and harmful effects of different drugs in vivo.

The animal models may develop cancer spontaneously or by genetically altering key genes. Exposure to environmental factors may also lead to cancer development. Furthermore, mouse xenograft models can be used to study human tumors in vivo, by placing human tumors into an immunologically deficient mouse model.

In this thesis, two mouse models were used to study breast cancer in vivo, the genetically altered MMTV-PyMT mouse model and the xenograft nude mouse models.

\section{MMTV-PyMT mouse model}

To develop a transgenic mouse model, oncogenes such as TGF- $a, c-M y c$, and polyoma middle T antigen (PyMT), are expressed under the control of several promoters such as the mouse mammary tumor virus promoter (MMTV). This type of model is usually based on the mutation of a single gene, which can be a disadvantage compared to the high complexity and heterogeneity of human tumors. However, the immune system of the transgenic mouse is not compromised, as in the xenograft mouse model. The PyMT mouse model therefore mimics the natural tumor microenvironment and offers an excellent model to study the stepwise development of cancer, and to study the interplay between cancer cells and stromal cells. 
In the MMTV-PyMT transgenic mouse model, the mammary gland-specific expression of PyMT is under the control of the MMTV promoter/enhancer, resulting in the development of multifocal mammary adenocarcinomas. Although the polyoma middle $T$ antigen is not found in human breast cancer (229), the PyMT mouse model has nonetheless proven to be a reliable model of breast cancer, especially in studies of metastasis (230).

In this thesis, the immune competent PyMT mouse model was used. The transgenic female $\mathrm{FVB} / \mathrm{n}$ mouse expressing PyMT antigen under the control of the MMTV long terminal repeat, developed spontaneous adenocarcinomas of all mammary epithelia by 8-10 weeks of age. These spontaneous tumors were removed and dissociated in a collagenase/dispase solution to generate a single cell suspension. The cells were cultured until confluent, then injected into the dorsal mammary fat pad of female oopherectomized FVB mice. To create a homogeneous population with controlled estrogen exposure, the mice were ovariectomized and implanted subcutaneously in the neck with $3 \mathrm{~mm}$ pellets containing $17 \beta$-estradiol.

Several investigators have shown that MMTV-PyMT breast cancers expressed the estrogen receptor (ER) at significant levels at early carcinoma stages, and that this ER expression was gradually lost during tumor progression (231). Therefore, the effects of estradiol on these tumors were investigated in this study (Fig. 10).

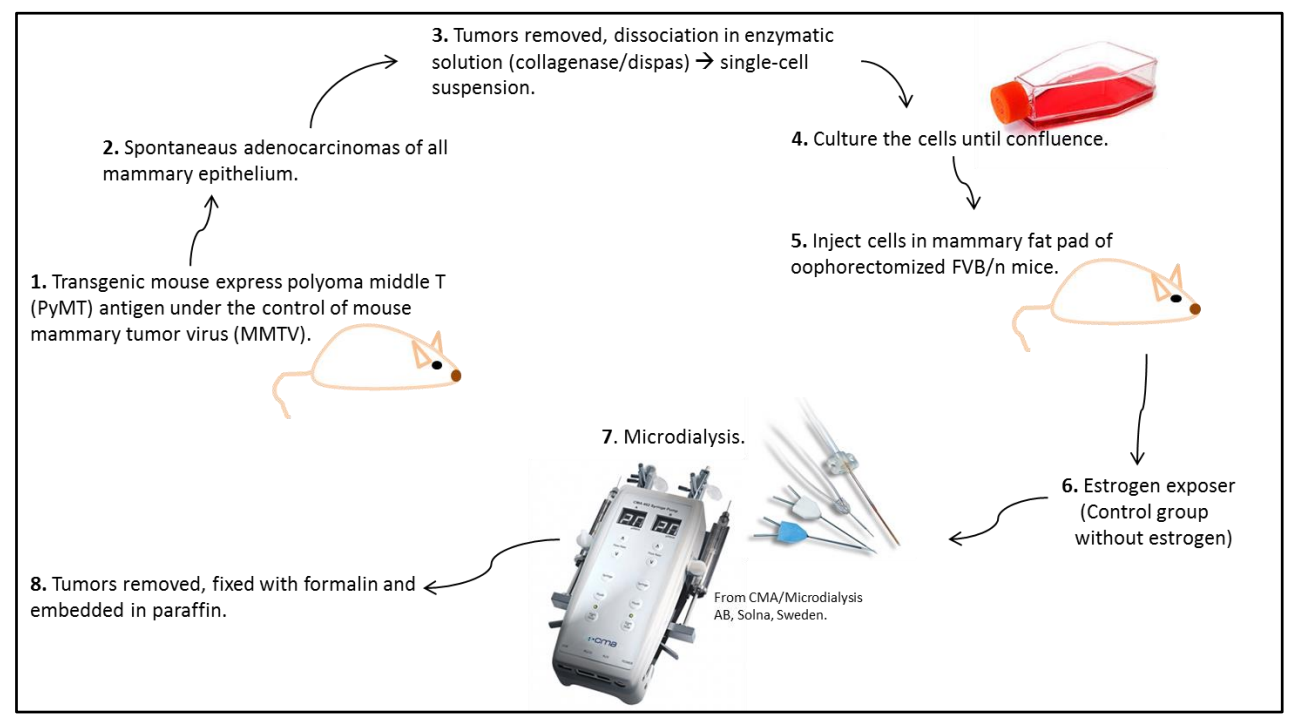

Figure 10. In the PYMT mice model, cultured cells separated from adenocarcinomas tumors removed from FVB/n mice transgenic expressing PyMT antigen under the control of MMTV, were injected in the dorsal mammary fat pad of oopherectomized FVB/n mice. The tumor-bearing mice were divided into a control and an estrogen group, where the mice were subcutaneously implantated with a $3 \mathrm{~mm}$ pellets containing 176-estradiol, $0.18 \mathrm{mg} / 60$-day releases, in the neck. Microdialysis was performed and tumors were then extracted for further analysis 


\section{The nude mouse xenograft model}

The nude mouse has a mutation in the FOXN1 gene, which causes absence of a thymus and a major reduction in the number of T lymphocytes. This mouse strain lacks body hair and also lacks a rejection response, which makes it suitable for human cancer research. The complete defect in the thymus in this model is a great drawback when investigating the immune system response in cancer. However, the activity of the cytotoxic cells, NK cells, and macrophages in these mice is much greater compared to their euthymic counterparts (232). Certain immunological tumor concept can therefore still be investigated using this model. Human tumor xenografts are good models for reproduction of the histological pattern of human tumors, even at an advanced stage when cells migrate to distant metastatic sites (233).

Compared to spontaneous murine mammary carcinoma models, the use of actual human cancer cells in nude mice makes it a much better model for studying the hormone responsiveness of tumors. The murine mammary model expresses low levels of estrogen and progesterone receptors and responds poorly to hormones, while approximately $80 \%$ of all breast cancer patient that are positive for ER can benefit from endocrine therapy (234).

In this thesis, the immune deficient nude mouse model was used to study the effects of tamoxifen exposure. The ovaries from female mice at the ages of 6-8 weeks were surgical removed before the subcutaneously implantation of $3 \mathrm{~mm}$ pellets containing $17 \beta$-estradiol in the neck, involving $0.18 \mathrm{mg} / 60$ day release. The $17 \beta$-estradiol pellet ensured a constant and stable release of estradiol at physiological serum concentrations of 150-250 pM, representing the physiological estrogen levels observed during the estrous cycle in mice and the menstrual cycle in women. One week after surgery, $5 \times 10^{6}$ MCF7 cells in $200 \mu \mathrm{l} \mathrm{PBS}$ were injected into the dorsal mammary fat pad of nude mice. The animals were treated with s.c. injections of $1 \mathrm{mg}$ tamoxifen, every other day, to reproduce a serum concentration equal to the therapeutic serum concentration in human breast cancer patients. Because the growth of MCF7 tumors is estrogen-dependent in nude mice, it was impossible to include a group without estrogen or with only tamoxifen in this study. However, the presence of estrogen during the tamoxifen treatment reflected the tumor microenvironment in both pre- and postmenopausal breast cancer patients. Intratumoral microdialysis was then performed on mice before tumor extraction (for further details, see Fig. 11). 


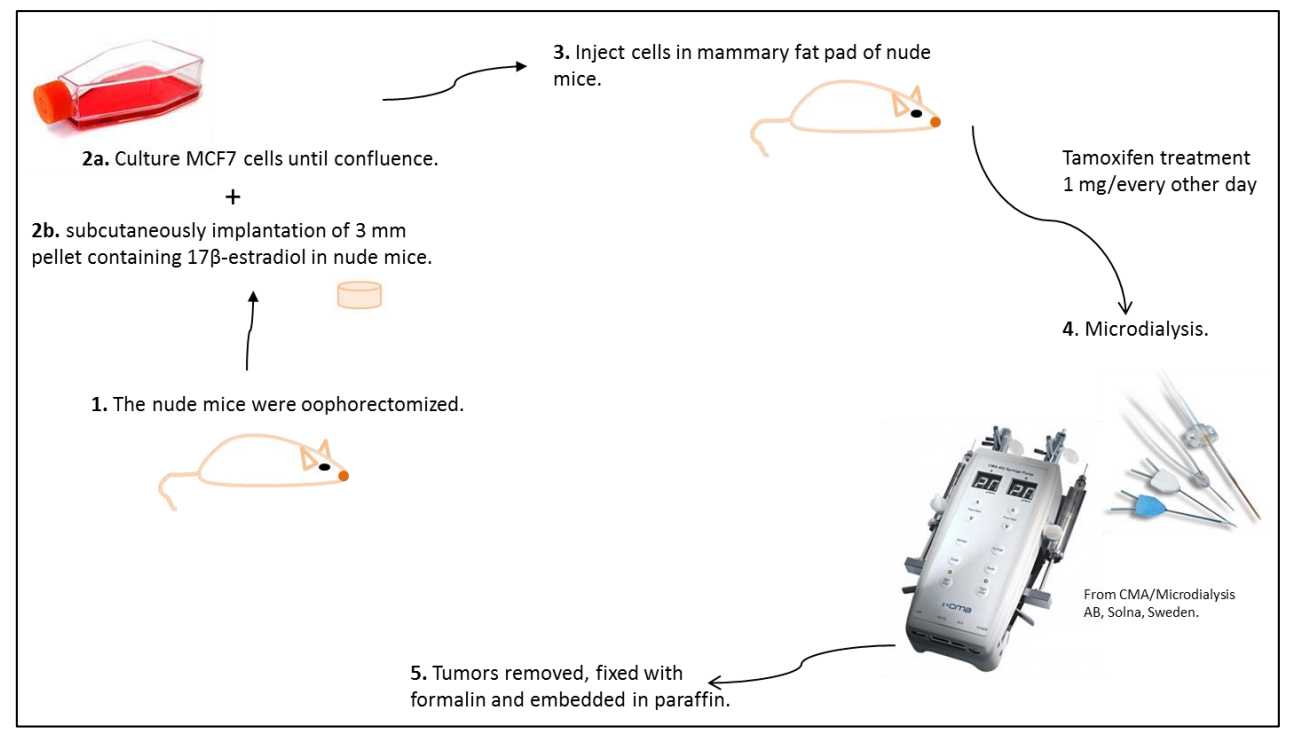

Figure 11. In the nude xenograft mice model, the MCF-7 cultured cells were injected in the dorsal mammary fat pad of oopherectomized nude mice, after one week of implantation of $3 \mathrm{~mm}$ pellets containing 176-estradiol. The tumor-bearing mice are treated with $1 \mathrm{mg}$ tamoxifen every other day. Microdialysis was performed and tumors were then extracted for further analysis.

\section{Immunohistochemistry}

Immunohistochemistry (IHC) is a biochemical technique commonly used to detect the presence of a particular antigen in tissue using a specific antibody. This method is widely used in molecular biology and clinical analyses, because it is relatively inexpensive, highly sensitive, quite reproducible, and fast. However, IHC has a major disadvantage in the staining of proteins of interest, as in other methods such as the western blot, where antibody staining is checked against a molecular weight ladder. IHC depends on qualitative observation, which leads to difficulties in interpreting the staining result because it requires a manual scoring system that relies on the quality of the antibodies used, and on the length of time the tissue sections have been exposed.

Prior to immunohistochemical staining, the tissue needs to be prepared by fixation, usually in formalin and to a lesser extent in alcohol, and then paraffin-embedded for preservation and easier storage. During the fixation process, paraformaldehyde will penetrate the tissue, crosslink the proteins, and stop all enzymatic degradation. During immunohistochemical staining, all effects produced by formalin fixation need to be removed for antigen retrieval to make the epitopes available for antibody binding. In this thesis, the fixation and paraffin embedding steps were performed by a member of the staff at the Division of Pathology at Linköping's University.

The paraffin-embedded tissues were usually cut into $4 \mu \mathrm{m}$ sections by a microtome and placed on slides. The staining process started with the deparaffinization of the formalinfixed paraffin-embedded tissue sections in xylene or in Tissue-Clear ${ }^{\circledR}$, followed by 
dehydration steps with increasing concentrations of alcohol. The sections were pretreated with high temperature or a protease during the antigen retrieval step to destroy the proteins crosslink induced by fixation. Endogenous enzyme activity was also blocked by hydrogen peroxide $\left(\mathrm{H}_{2} \mathrm{O}_{2}\right)$ before antibody treatment. Both monoclonal and polyclonal primary antibodies were used for IHC, although polyclonal antibodies could sometimes contribute to enhanced risk of cross-reactivity and background staining. Monoclonal antibodies are derived from a single B cell clone. They recognize a single epitope on the antigen, while polyclonal antibodies recognize several different epitopes because they originate from multiple $B$ cell clones. The primary antibodies, diluted in a protein solution to avoid nonspecific binding, were incubated at $4^{\circ} \mathrm{C}$ overnight in a moisturized chamber, to prevent tissue dehydration. The optimal antibody concentration was determined by titration experiments for each antibody. Primary antibodies were used to recognize the antigen of interest while a secondary antibody was used for the detection. The secondary antibodies targeted the immunoglobulins of the primary antibody species, and were usually linked to a enzymatic reporter such as horseradish peroxidase (HRP), which produced a brown staining in the presence of its substrate, 3,3'-diminobenzidine (DAB). The sections could also be counterstained using Mayer's hematoxylin in order to visualize the nuclei before the final dehydration and mounting steps, followed by visualization of the slide under a light microscope (Fig. 12).

Table1. List of all primary and secondary antibodies used in this thesis.

\section{Primary antibodies}

\begin{tabular}{llllc}
\hline Antibody & Host species & $\begin{array}{l}\text { Species } \\
\text { reactivity }\end{array}$ & Supplier & $\begin{array}{c}\text { Concentration } \\
(\boldsymbol{\mu g} / \mathbf{m l})\end{array}$ \\
\hline anti-IL-1 $\alpha$ & Mouse & Human & R\&D Systems & 5 \\
anti-IL-1 $\beta$ & Mouse & Human & R\&D Systems & 25 \\
anti-IL-1Ra & Goat & Human & R\&D Systems & 15 \\
anti-IL-1RI & Rabbit & Human & GeneTex & 4 \\
anti-IL-1RII & Rabbit & Human & Lifespan biosciences & 10 \\
anti-IL-1RI & Rat & Mouse & LSBio & 10 \\
anti-IL-1RII & Goat & Mouse & R\&D Systems & 10 \\
anti-leptin & Rabbit & Human & GenWay Biotech & 1 \\
anti-Ob-R & Goat & Human & AbD Serotec & 20 \\
anti-adiponectin & Rabbit & Human & Abcam & 1 \\
anti-adipoR1 & Rabbit & Human & Bioss & 5 \\
anti-adipoR2 & Rabbit & Human & Bioss & 5 \\
\hline
\end{tabular}

\section{Secondary antibodies}

\begin{tabular}{llllc}
\hline Antibody & Host species & Conjugate & Supplier & Dilution \\
\hline anti-Goat & Bovine & HRP & Santa Cruz Biotech. & $1: 200$ \\
anti-Rat & Goat & HRP & Abcam & $1: 1000$ \\
anti-Rabbit & Goat & Envision HRP & DAKO & - \\
anti-Mouse & Goat & Envision HRP & DAKO & -
\end{tabular}




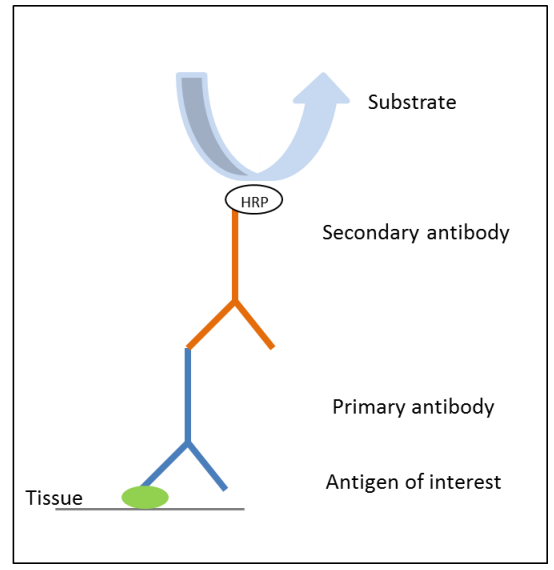

Figure 12. A schematic picture for IHC technique. Primary antibody will recognize and bind to a specific antigen if present in tissue section. A secondary antibody conjugated with an enzyme is added to recognize the first antibody. A substrate is then used to activate the enzymatic reaction and create a color change for detection.

In this thesis, IHC was used to detect the presence of the IL-1 cytokine family proteins (IL-1 $\alpha$, IL-1 $\beta$, IL$1 R a, I L-1 R I$, and IL-1RII), and adipokines (leptin, adiponectin, leptin receptor, and adiponectin receptors 1 and 2) in paraffin-embedded tissues. Normal human breast tissue biopsies collected after seven days of treatment with different hormones, were paraffin-embedded and subjected to IHC. Tumor tissue from animal models, both the immune competent PyMT mouse model and the immune deficient nude mouse model, were extracted after microdialyses, paraffin-embedded, and stained by IHC. A list of all antibodies used is shown in table 1. An Olympus BX43 microscope was used to visualize the staining, and digital images were captured using an Olympus DP72 camera. Images of 7-10 random fields (400x) of 3-6 individual tumors/tissues in each group were analyzed. For all experiments, control sections incubated without the primary antibody showed no staining.

\section{ELISA}

The enzyme-linked immunosorbent assay (ELISA) is a biochemical technique used to detect and quantify such diverse substances as peptides, proteins, growth factors, antibodies, and hormones. ELISA is a specific, highly sensitive, and relatively easy to use method, which makes it a valuable as an in vitro diagnostic tool in medicine and a valuable quality control test in industries. It is also quick and easy to perform for many samples at a time. Compared

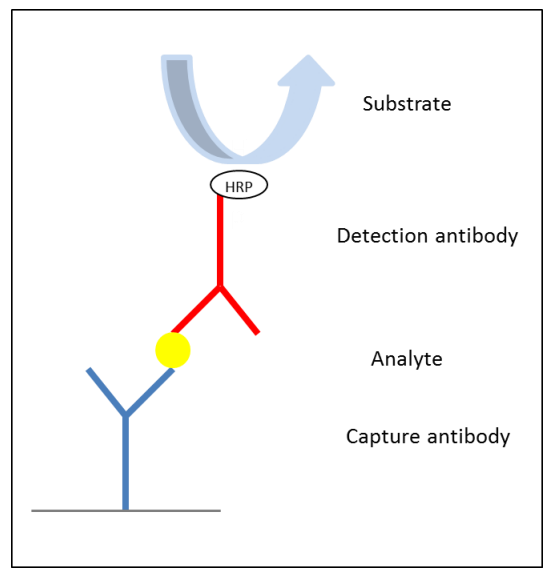

to other immunoassay methods such as radioimmunoassay (RIA) tests, ELISA is less costly and safer because no radioactive substances are used. However, in contrast to Luminex ${ }^{\circledR}$ assays, which allow the measurement of multiple proteins in the same aliquot of sample, ELISA can only measure a single protein in each sample.

Figure 13. A schematic picture for ELISA technique. The microplate is pre-coated with capture antibody which will bind its specific analyte if present in the samples. A second enzyme (HRP)-conjugated antibody, detection antibody, will bind to the captured analyte. The addition of substrate will activate the enzymatic reaction and create a color change for detection. 
This technique determines the interaction between an antibody and its antigen, usually as a sandwich enzyme immunoassay. The antigen in a sandwich ELISA is specifically captured on a solid surface such as a microtiter plate, usually by linking it to a monoclonal capture antibody, which is specific to the antigen. A detecting antibody, which is covalently coupled to an enzyme, is then added to the studied antigen followed by an enzymatic substrate, which will produce a visible signal that indicates the amount of antigen in the sample. To remove nonspecifically bound antigen or antibody, the microtiter plate is washed several times between each step (Fig. 13).

In this thesis, commercial human and murine immunoassay kits based on quantitative sandwich enzyme immunoassay techniques were used for the detection of immune modulators such as members of the IL-1 cytokine family, leptin, adiponectin, and VEGF, and the analytes collected from all microdialysis experiments, both from human subjects and animal models. In addition, supernatants collected after hormone treatment of normal breast biopsies were analyzed using the ELISA. The amount of each studied antigen was quantified using a standard curve.

The commercial kit used for the measurement of IL-1 cytokine family members, leptin, and adiponectin used the colorimetric assay, Quantikine ${ }^{\circledR}$, in which a chromogen is added into the wells after incubation with horseradish peroxidase-conjugated secondary antibodies. Oxidation occurs and a blue color develops. An acid is then used to stop the reaction and to generate a yellow color measured by a spectrophotometer.

QuantiGlo ${ }^{\circledR}$, another detection technique, was used to quantify VEGF in the collected samples because of its wide dynamic range, compared to the standard Quantikine ${ }^{\circledR}$ ELISA. The QuantiGlo ${ }^{\circledast}$ technology is based on the use of a chemiluminescent substrate that is read by a luminometer, measuring the intensity of emitted light as relative light units (RLU).

In this thesis, another type of ELISA, based on the principle of competitive binding, was used to quantify the estrogen and progesterone levels in plasma and microdialysates from healthy donors and breast cancer patients. With this commercial ELISA kit, the measured hormone in the sample competes with the same hormone conjugated with horseradish peroxidase, so the amount of the peroxidase-conjugate hormone is inversely proportional to the concentration of the measured hormone, and the intensity of the color produced by adding a substrate is therefore also inversely proportional to the concentration of the measured hormone. 


\section{Statistics}

In both Paper I and Paper II, paired Student's $t$-tests were used to analyze the date collected from the same subjects in a group before and after changes in a single parameter, such as a treatment condition. Unpaired Student's $t$-test was used to compare data sets collected from two different groups. ANOVA were used if the group numbers were higher than two. Pearson's correlation coefficient was used to study the relationship between the groups, and a value of $\mathrm{P}<0.05$ was considered statistically significant. However, other nonparametric tests, such as the Wilcoxon rank-sum test (also called the Mann-Whitney $U$ test), the Wilcoxon signed-rank test, and Spearman's rank correlation coefficient, could also be used.

In Paper III, we used an unpaired Student's $t$-test to compare two data sets collected from two different groups. Spearman's rank correlation coefficient was used to study the relationships between the different groups to find both linear and nonlinear correlations. A value of $P<0.05$ was considered statistically significant.

Data were presented as mean \pm SEM in all papers and all analyses were performed using Graphpad Prism (version 5.04, GraphPad Software, Inc. USA). 


\section{Results and discussion}

Inflammation is one of the hallmarks of cancer development (1). The interleukin-1 (IL-1) family is one of the central regulators of the immune and inflammatory responses (93). IL-1, together with TNF- $\alpha$, represents the "alarm cytokines" which induce the expression of diverse inflammatory genes. These inflammatory cytokines generate a local cascade that initiates, spreads, and sustains the inflammatory response $(99,235,236)$. IL-1 is thought to play an important role in cancer progression. IL-1 $\alpha$, IL-1 $\beta$, and IL-1 receptor antagonist (IL$1 \mathrm{Ra})$ are the most well-known members of the IL-1 cytokine family.

Our group previously reported the release of IL-1s from both cancer and stromal cells in a xenograft nude mouse model, and an alteration of IL-1 levels after tamoxifen or diet modification by flaxseed and lignan enterolactone, but not by genistein (237). In Paper I of this thesis, we therefore intended first to determine the presence of IL-1 cytokines in the extracellular space of human breast tissue in vivo, and to investigate the role of sex steroids in the regulation of IL-1 cytokines in normal human breast tissue. In addition, we wanted to determine the effects of nutrition and anti-estrogen drugs on the levels of IL-1 in normal breast tissue in vivo, and determine whether IL-1 cytokines were up- or down-regulated in breast cancer tumors in vivo.

The extracellular space is a biologically active site for the majority of the proinflammatory cytokines, and neither IL-1 $\alpha$ nor IL-1 $\beta$ are detected in the blood. We therefore used microdialysis methodology to sample IL-1 in breast tissue in vivo. Compared to other techniques, microdialysis is the only sampling technique capable of characterizing extracellular proteins without fluid loss, and with a minimal disturbances to the physiological condition of the tissue $(219,220)$. Several studies have demonstrated the capability of using microdialysis to measure proteins in the extracellular space, despite theirs absence or low presence in the blood $(189,223,226,238,239)$. Forty-one women were included in the studies in Paper I. They were studied using microdialysis under various hormonal exposures, tamoxifen therapies, and diet modifications. The collected samples were analyzed by ELISAs for IL-1 $\alpha, \mathrm{IL}-1 \beta$, and IL-1Ra. Human breast tissue biopsies, obtained from reduction mammoplasty, were cultured in different treatment conditions, and both the media and the biopsies were analyzed by ELISA and immunohistochemistry, respectively, for their content of IL-1 cytokines.

In Paper I, we showed the presence of IL-1 $\alpha$, IL-1 $\beta$, and IL-1Ra in normal breast tissue in vivo, although the levels of IL- $1 \alpha$ were low, probably because IL- $1 \alpha$ is an intracellular protein. We reported significant positive correlations between plasma estradiol levels and extracellular IL-1 $\beta$, and a strong and significant negative correlation between estradiol and IL-1Ra in normal breast tissue. These correlations may suggest estrogen dependency of these cytokines. We also showed a significant increase in IL-1 $\beta$ levels and a significant decrease in IL-1Ra levels in breast tissue in the luteal phase of a single menstrual cycle, when the levels of estradiol and progesterone were increased. However, we did not find any change in IL-1 $\alpha$ levels during hormonal changes in the menstrual cycle. These in vivo results may suggest an induction of a proinflammatory state in normal human breast tissue, consisted with previous clinical studies measuring IL-1 levels in tissue extracts, which 
suggested that higher levels of IL-1 $\beta$ were associated with an aggressive cancer phenotype, while higher levels of IL-1Ra were associated with a better outcome (240).

Treatment with tamoxifen reduced the risk of developing breast cancer by up to $40 \%$ in both pre- and postmenopausal women, but this treatment was associated with severe side effects such as endometrial cancer (61). Thus, new preventive strategies for breast cancer are needed. Diet modification may be one option because recent epidemiological studies have shown a reduction effect of dietary plant lignans in breast cancer patients (241-243). In Paper I, we found a significant increase of IL-1Ra levels and no changes in IL-1 $\alpha$ and IL-1 $\beta$ levels in normal breast tissue of postmenopausal cancer patients receiving tamoxifen for six weeks as adjuvant therapy. Similar results were obtained by daily addition of $25 \mathrm{~g}$ of freshly ground flaxseed administered to premenopausal healthy volunteers for 30 days. This equal alteration in IL-1Ra levels, the naturally occurring antagonist of the IL-1 family, by tamoxifen therapy and flaxseed diet suggested that diet modification might be an effective prevention tool in breast cancer treatment. It also suggested that alterations in IL-1Ra might shift the milieu in normal breast tissue towards an anti-inflammatory microenvironment. These findings were further validated using ex vivo experiments on whole breast tissue biopsies from reduction mammoplasties of premenopausal women, cultured in the presence or absence of hormones/anti-hormones. The ex vivo experiments confirmed the results obtained in vivo.

We also showed that extracellular IL-1 $\beta$ levels were significantly increased in breast cancer tissue, compared with adjacent normal breast tissue, while IL-1 $\alpha$ and IL-1Ra levels were unaltered in 10 postmenopausal breast cancer patients studied by microdialysis, one day before surgery. These in vivo results suggested a more proinflammatory state in breast cancer tissue compared with normal adjacent breast tissue. By examining autopsy samples from women not known to have breast cancer, studies found in situ breast cancer in $15-30 \%$ of all women, although only $1 \%$ of the women in the same age group were diagnosed with breast cancer (171). The progression of these in situ breast cancers into invasive, clinically relevant breast cancer may have been mediated by changes in the microenvironment. Our findings might suggest IL-1 to be a potential modulator that may be altered in the breast microenvironment to induce a clinically relevant breast cancer.

To further investigate the hormonal regulation of IL-1, we studied the effect of estrogen/anti-estrogen on the expression levels of receptors for the IL-1 cytokine family. IL$1 \alpha, \mathrm{IL}-1 \beta$, and IL-1Ra exert their activity by binding to the same receptors, the IL-1 receptor type I (IL-1RI), and IL-1 receptor type II (IL-1RII), but with different affinities and diverse outcomes. The IL-1RI was capable of activating cells when binding to IL- $1 \alpha$ and IL-1 $\beta$, whereas IL-1RII was biologically inactive, regardless of its interactions partner (97). Tumor sections from both immune competent mice with murine breast cancer (PyMT transgenic mouse model) and immune deficient mice (nude mouse xenograft model) bearing human breast cancers were characterized using IHC staining to determine the expression levels of IL-1 receptors. IHC staining used antibodies against both murine and human IL-1RI and IL$1 \mathrm{RII}$ in paraffin-embedded tumor sections. We also used IHC to study the expression levels of human IL-1RI and IL-1RII in paraffin-embedded whole breast tissue biopsies from 
reduction mammoplasties of premenopausal women, cultured in the presence or absence of hormones/anti-hormones. Unfortunately, we did not find any differences in intensity of the staining between the treatments.

To investigate the effects of estradiol/anti-estrogen therapy on the expression of IL-1RI and IL-1RII in human ER+ breast cancer cell lines (MCF7 and ZR-75-1) in vitro, we treated the breast cancer cell lines with estradiol, tamoxifen, and fulvestrand (alone or in combination) for seven days. After treatment, the cell supernatant and cell lysate were analyzed using ELISA for the expression of soluble and membrane bound IL-1RI and IL-1RII. Unfortunately, there were no detectable levels of IL-1RII receptor in our treated cells. IL-1RI was deceased by estrogen exposure and increased by both tamoxifen and fulvestrand treatment in both breast cancer cell lines. This result is consistent with other studies showing negative regulation of mRNA IL-1RI by estrogen in human osteoclasts-like cells (244).

Western blot was also used to analyze the expression levels of IL-1RI and IL-1RII, but the results were unsatisfactory due to technical difficulties involving detection of several bands. To define these bands, we crosslinked the anti-IL-1RI antibody to protein $\mathrm{G}$ magnetic breads, and after incubation with the cell lysate from treated breast cancer cell lines, we eluted the binding proteins, resolved them using sodium dodecyl sulfate polyacryamid gel electrophoresis (SDS-PAGE), followed by staining with Coomassie Brilliant blue. Unfortunately, no significant bands were detected.

Table 2. The characteristics of the breast cancer cell lines included in this work.

\begin{tabular}{|l|l|l|}
\hline MCF7 & $\underline{\text { ZR-75-1 }}$ & MDAMB231: \\
Invasive breast ductal & Invasive breast ductal & Breast adenocarcinoma \\
carcinoma & ER+ & ER \\
PR+ & PR- & PR- \\
HER2- & HER2- & HER2- \\
$\begin{array}{l}\text { Tumorigenic in mice but only } \\
\text { with estrogen supplementation }\end{array}$ & Tumorigenic in mice. & Tumorigenic in mice. \\
Low metastatic properties & High metastatic properties & High metastatic properties \\
& (bone metastasis) & \\
\hline
\end{tabular}

Findings from Paper I prompted us to test whether other members of the IL-1 family were present in the extracellular space of breast tissues. IL-18, a IL-1 cytokine member with dual effects in cancer $(245,246)$, is expressed in macrophages, dendritic cells, Kupffer cells, keratinocytes, chondrocytes, synovial fibroblasts, and osteoblasts (247). In addition, the newest identified member of the IL-1 family, IL-33, also called IL-1F11, may have role in tumor progression. Immune cells such as dendritic cells and macrophages, as well as fibroblasts, endothelial cells, and epithelial cells express IL-33 (248). Unfortunately, IL-18 
was not detected in either the in vivo microdialysate from human subjects or from the supernatant collected from breast cancer cell lines treated with hormones/anti-hormones in vitro. IL-33 was present in the extracellular space of breast tissues, but at low levels. Very low levels of IL-33 were also found in the supernatants collected from breast cancer cell lines treated with hormones/anti-hormones in vitro.

Table 3. Table for all the member of the IL-1 cytokine family and their known receptors.

\begin{tabular}{|l|l|}
\hline Cytokine name & Receptor \\
\hline IL-1F1 (IL-1 $\alpha)$ & IL-1 RI, IL-1 RII \\
IL-1F2 (IL-1ß) & IL-1 RI, IL-1 RII \\
IL-1F3 (IL-1Ra) & IL-1 RI, IL-1 RII \\
IL-1F4 (IL-18) & IL-18R (IL-1R5) \\
IL-1F5 & IL-1Rrp2 (IL-1R6) \\
IL-1F6 & IL-1Rrp2 (IL-1R6) \\
IL-1F7 & IL-18R (IL-1R5) \\
IL-1F8 & IL-1Rrp2 (IL-1R6) \\
IL-1F9 & IL-1Rrp2 (IL-1R6) \\
IL-1F10 & IL-1RI \\
IL-1F11 (IL-33) & T1/ST2 \\
\hline
\end{tabular}

Results from analyses of IL-18 and IL-33 were inconclusive, therefore a literature search was conducted to identify possible cooperative partners for IL-1 in breast cancer. A study by Zhou et al. reported increased expression of all IL-1 system components (IL-1 $\alpha$, IL-1 $\beta$, IL-1Ra, and IL-1RI) when mouse mammary cancer 4T1 cells were treated with leptin (249). Miyoshi et al. reported that both leptin and leptin receptor (Ob-R) were detected in high levels in human breast carcinoma cells, but not in normal cells (250). We therefore included the adipocytokines leptin, as well as adiponectin, a protein also produced by white adipose tissue, in our studies. Adipokines are diverse, soluble, bioactive molecules produced by adipocytes, which constitute the most abundant cell type surrounding the epithelial and mammary cells in the breast $(110,111)$. Leptin is a proinflammatory, pro-angiogenic, adipose-derived hormone that functions by binding to Ob-R (111). Adiponectin has an important role in regulating several metabolic processes such as lipid synthesis and energy homeostasis $(138,251)$. Several studies have investigated the relationships between leptin and adiponectin in breast cancer, using their expression levels either in circulation or in tumor homogenates as a measure of their local expression in the breast. Conflicting results have been reported regarding the relationship between serum leptin and breast cancer, but several of these studies reported that higher leptin serum levels were associated with breast cancer (252). In contrast, adiponectin exhibited lower levels in breast cancer among postmenopausal women, compared to healthy controls $(150,151,253)$. Furthermore, the leptin:adiponectin ratio may be the key to understanding the physiological effects of these adipokines in several diseases $(163,164)$. 
Understanding the relation between IL-1, adipokines, and other immune modulators in the tumor microenvironment will provide important information to help elucidate molecular mechanisms and therapeutics. The following critical objectives need to be examined: 1) Do the adipokines exist in the extracellular space of normal and cancerous breast tissue in vivo?, and 2) What are the effects of sex steroids on adipokine levels in normal breast tissue in vivo? Estrogen correlated positively with serum leptin, but not serum adiponectin, in premenopausal healthy women according to report by Hong et al. (254), but it was unclear if a correlation also exist in the tumor microenvironment. We therefore decided to investigate 40 women (Paper II) using the microdialysis technique. The healthy women were investigated under various hormone exposures, while the breast cancer patients were investigated before surgery or before and after tamoxifen treatment. Two in vivo mouse models, the PyMT transgenic mouse model and the nude mouse xenograft model, were also used in this study, as well as cultured ex vivo breast tissue biopsies obtained from reduction mammoplasties.

Leptin is a $16 \mathrm{kDa}$ protein and adiponectin is a $30 \mathrm{kDa}$ hormone. Both these adipokines can easily be sampled using microdialysis with a $100 \mathrm{kDa}$ cut-off semipermeable membrane. However, studies have suggested that adiponectin is not present as a monomeric protein in serum, but rather as oligomeric multimers. These multimers can be trimers (low molecular weight, LMW), hexamers (medium molecular weight, MMW), or multimers (higher molecular weight, HMW) (255). If adiponectin in the extracellular space also exists in a multimeric structure, it will not be possible to sample with the $100 \mathrm{kDa}$ cut-off membrane. In Paper II, we confirmed the presence of both adipokines in normal and cancerous breast tissue in vivo. Adiponectin was successfully collected, and there were significant differences between different treatments, which may suggest that at least a significant proportion of adiponectin existed in its monomeric form in the extracellular space of the breast.

Microdialysis was performed in 11 breast cancer patients before surgical removal of the tumor. One microdialysis catheter was inserted intratumorally into the cancer tissue, and one microdialysis catheter was inserted into normal adjacent tissue. Leptin levels were significantly higher in breast cancer tumors compared with normal adjacent breast tissue, whereas adiponectin levels were significantly lower. These results agreed with the results obtained from several studies investigating the relationship between serum adipokines and breast cancer $(132,150,151,164,253,256)$. In addition, we found that plasma estradiol levels correlated positively with local extracellular leptin levels, and negatively with local extracellular adiponectin levels in normal breast tissue, but not in s.c. abdominal fat. We also found a local reduction of extracellular adiponectin levels and a local increase of leptin levels during the luteal phase of a single menstrual cycle in premenopausal healthy volunteers. These results suggested that estrogen might be an important regulator of the production of both leptin and adiponectin in normal breast tissue. To confirm these in vivo results, whole normal breast tissue biopsies were cultured ex vivo in the presence or absence of hormones. Estradiol treatment, but not progesterone treatment, increased leptin levels and decreased adiponectin levels in the culture medium. 
In addition, a PyMT breast cancer mouse model was characterized in the presence or absence of estrogen. We found that cancers grown in the presence of estradiol exhibited higher leptin levels and leptin:adiponectin ratios compared with cancers in estrogendepleted mice. Although the adiponectin levels seemed to decrease, this reduction was not significant. These results may also implicate estrogen in the regulation of leptin production, but not adiponectin production in murine cancer tissue.

We also reported a significant decrease of leptin levels and significant increase of adiponectin levels in normal breast tissue of 18 postmenopausal women receiving tamoxifen as an adjuvant therapy. This finding strongly indicated that tamoxifen attenuated the effect of estrogen in adipokine levels in normal breast tissue. The validations of these in vivo results were confirmed in ex vivo culture of normal breast tissue biopsies, which showed decreased secretion of leptin and increased secretion of adiponectin after tamoxifen treatment. However, we were unable to confirm these conclusions using in vivo study involving tamoxifen treatment of xenograft nude mice bearing MCF7 tumors, because adiponectin levels were not detectable.

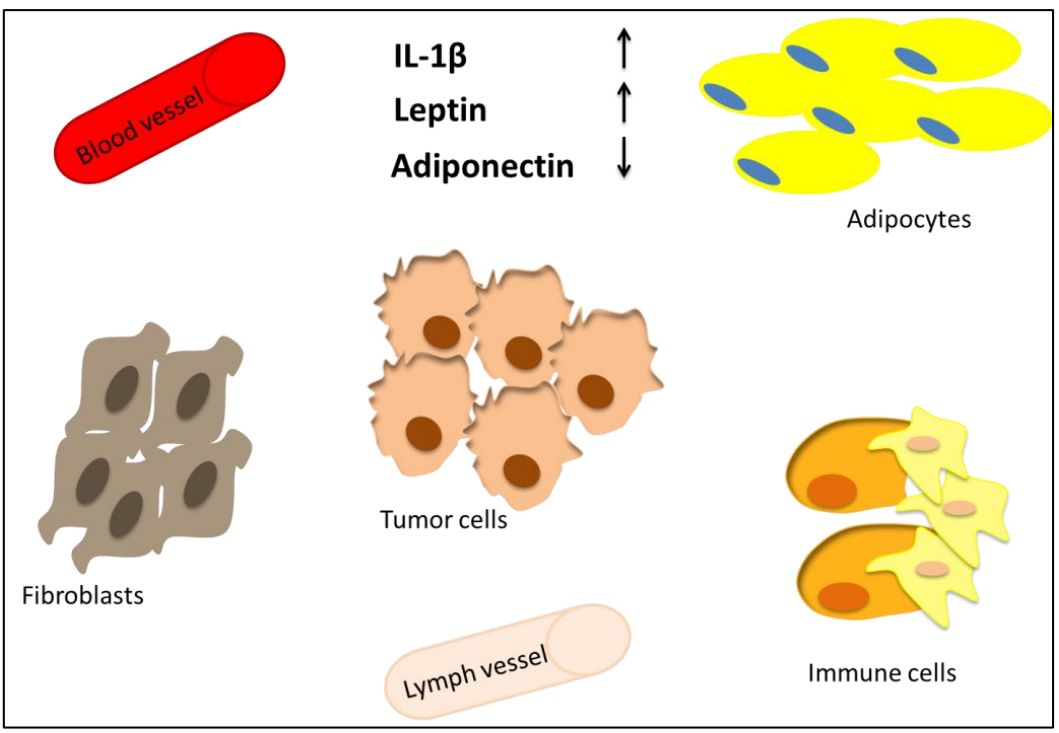

Figure 14. The immune modulators in the extracellular space of breast cancer tissue.

The existence of adipokines in the extracellular space of breast cancer tissues and the hormonal regulation of adipokines in normal human breast tissues were demonstrated using both in vivo and ex vivo experiments in Paper II. However, the interactions between IL1 , adipokines, and other immune modulators such as VEGF, also found by our group in the extracellular space of normal breast tissue $(226,257)$, and the role of estrogen on these interactions are unknown. We therefore treated breast cancer cell lines (MCF7 and MB231, an ER- breast cancer cell line) with or without estrogen, with tamoxifen, leptin, and their combination, to determine their effects on IL-1, adipokines, and VEGF at the gene level 
using real-time polymerase chain reaction (PCR). Unfortunately, mRNA levels were too low for detection of IL-1 $\alpha$ and IL-1 $\beta$ genes, even though pre-amplification was performed.

Microdialysis was used to find any correlation between the extracellular levels of IL-1, leptin, adiponectin, and/or VEGF in normal human breast tissue. In vitro co-culture models of mature human adipocytes and breast cancer cell lines were used to elucidate the role of adipocytes in the regulation of these modulators.

In Paper III, we showed that VEGF levels correlated significantly with leptin, and the ratio of leptin to adiponectin in normal breast tissue, but not in s.c. abdominal fat tissue. These findings suggested tissue-specific regulation between VEGF and leptin in the breast. To investigate this relationship, in vitro co-culture models of mature human adipocytes and breast cancer cell lines were used. A neutralization experiment, using antibodies against VEGF and leptin, suggested that VEGF was regulator of leptin, but that leptin was not a regulator of VEGF. However, these results could not exclude the possibility of an indirect regulation between leptin and VEGF, because other studies have suggested that IL-1s could be mediators in the interactions between VEGF and leptin (249). The role of adipocytes was shown in the co-culture model, where extracellular levels of leptin and VEGF were enhanced in co-culture compared to monocultures of the included cells. These results illustrated the importance of intracellular communication in the microenvironment. Furthermore, the effects of estradiol exposure were enhanced in co-cultures and the effects seemed to be mediated by ER dependent pathways, because treatment with fulvestrant, an anti-ER antagonist, altered these enhanced effects by estradiol.

In breast tissue, IL-1 $\beta$ significantly correlated with leptin and with VEGF in normal breast tissue in vivo, suggesting a potential effect of IL-1 $\beta$ in the regulation of leptin. Unfortunately, this possible correlation could not be investigated, because IL-1 $\beta$ was undetectable in all our experiments.

Taken together, the results from Paper III suggested important effects of these factors on each other in normal human breast tissue, and further suggested that physical contact between adipocytes and breast cancer cells could influence the phenotypic behaviors of these cells and enhance the effects of estradiol. 


\section{Conclusions}

- IL-1s and adipokines may be under the control of estrogen in vivo, and these cytokines may be attenuated by anti-estrogen therapy and diet modifications.

In Paper I: Estrogen increased the levels of IL-1 $\beta$ and decreased the levels of IL-1Ra in normal human breast tissue in vivo. Tamoxifen therapy and flaxseed diet increased IL-1Ra levels in normal human breast tissue in vivo.

In Paper II: Estrogen and tamoxifen altered leptin and adiponectin levels in normal human breast in vivo. These finding were confirmed by breast tissue biopsies from reduction mammoplasties cultured in the presence or absence of estrogen or tamoxifen.

- Breast cancers express a pro-tumorigenic profile of IL-1 and adipokines compared to adjacent normal breast tissue. In Paper I: IL-1 $\beta$ levels increased in breast cancer compared with normal adjacent breast tissue. In Paper II: Leptin levels were increased and adiponectin levels were decreased compared to adjacent normal breast tissue.

- Physical contact between adipocytes and breast cancer cells may influence the phenotypic behaviors of these cells and enhance the effects of estradiol on VEGF and leptin. In Paper III: Co-culture of adipocytes and breast cancer cells per se increased the secretion of VEGF and leptin, and enhanced the effects of estradiol compared to cultures of either cell type alone.

- VEGF, leptin, and IL-1 $\beta$ may influence each other in normal human breast tissue. In Paper III: Significant positive correlations between VEGF and leptin, and VEGF and leptin:adiponectin ratios were detected in normal breast tissue in vivo. IL-1 $\beta$ correlated significantly with leptin and VEGF in breast tissue. No correlations were found in s.c. abdominal fat tissue. 


\section{Reflections and future aspects}

Breast cancer is still the most frequently occurring malignancy in women, despite significant progress in diagnostic and treatment strategies. Because the cellular microenvironment is involved in tumor progression, invasion, and therapeutic responses, future research in this field has the opportunity to define new prevention and/or therapeutic strategies for this disease.

The results presented in this thesis suggested that IL-1 $\beta$, leptin, and adiponectin may be molecular targets for future prevention and therapeutic strategies in breast cancer. Higher expression of IL-1 $\beta$ and leptin, and a reduction in adiponectin levels were found in breast cancer compared with normal adjacent breast tissue. In addition, our results using normal human breast tissue suggested important regulatory effects between IL-1 1 , leptin, and VEGF, plus hormonal regulation of IL-1s and adipokines in normal human breast tissue, because estrogen altered the levels of these immune modulators while tamoxifen attenuated these effects in vivo. Several strategies for blocking the effects of IL-1 and VEGF are already used for treatment in numerous diseases, and leptin-blocking strategies are being investigated as new options for treatments of some autoimmune diseases. Recombinant IL-1Ra (anakinra) is an established drug for treatment of rheumatoid arthritis (104), and clonal antibodies to IL-1 $\beta$, together with a soluble receptor to IL-1, have also been approved for the treatment of chronic inflammatory diseases $(258,259)$. Anti-VEGF drugs (such as bevacizumab) are often combined with chemotherapy for cancer treatment (260). In addition, tyrosine kinase inhibitors have also been used in cancer patients to inhibit the action of the VEGF receptor (261). The activity of leptin is blocked by the use of leptin receptor antagonists, by specific antibodies against leptin, and by leptin binding proteins. Taken together, several speculative questions arise concerning whether a combination of these blocking strategies, or combinations for some of these blocking strategies with endocrine therapy, can be used as an option for treatment of breast cancer. Future in vitro and in vivo studies investigating the effect of combining IL-1 blockers with anti-VEGF, antileptin, and/or endocrine therapy in normal and malignant breast models, are of utmost importance in answering these questions.

Sex hormones are strongly implicated in the development of breast cancer, and the majority of breast cancers are hormone-dependent. Anti-estrogens, including tamoxifen and aromatase inhibitors, are essential for breast cancer treatment. Tamoxifen reduced the incidence of breast cancer by more than $40 \%$, but was associated with severe side effects such as thromboembolism and endometrial cancer $(59,253)$. Thus, there is a great need for new breast cancer treatments and preventive strategies. The effect of flaxseed (lignans), a class of phytoestrogens, was investigated in this thesis. The addition of flaxseed in the diet of healthy women showed a shift towards an anti-inflammatory environment by increasing IL-1Ra levels in normal breast tissue. Based upon these results, several important questions remain. Which other inflammatory cytokines (IL-6, TNF- $\alpha$ ), chemokines, and growth factors are altered? What is the effect of changing the diet by including other phytoestrogen compounds such as isoflavones? Isoflavones are rich in many foods, including tofu, soybeans, and soymilk, which are commonly consumed in Asian countries but not in 
Western countries. Epidemiological studies have either shown no protective association or a protective association between soy proteins and breast cancer. Future studies using microdialysis in both pre- and postmenopausal healthy women, together with in vitro and in vivo experimental models, are needed to explore the effects of phytoestrogens as possible prevention and/or therapeutic options for breast cancer. 


\section{Acknowledgements}

I would like to sincerely thank all the people who have helped me with this thesis. A special thanks goes out to:

My supervisor, prof. Charlotta Dabrosin, for accepting me as graduate student and for your excellent guidance and constructive feedback. You have a brilliant mind and are a source of knowledge. I will always admire your energy and your passion for research. Thank you for believing in me.

My co-supervisor, prof. Christina Ekerfelt, for giving me the opportunity to do a PhD and for your trust in me.

My co-author, friend, and colleague, Annelie Abrahamsson, for participating in all discussion about my work as well as sharing your laboratory expertise. Thank you for always being a calm, patient and supported person. Your remarks and thoughts along the way were invaluable. Thank you again for reading and commenting my thesis!

Ameet, roommate and colleague, for scientific discussions concerning leptin and a lot more. And for introducing me to the wonderful world of real time PCR.

Gaby, our pos-doc, for always being a happy and considerate colleague. I wish you all the best!

Gabriel Lindahl, for the collaboration with the BG-1 project. Good luck with your PhD.

All co-authors for your collaboration and valuable contributions

All patients and volunteers, which participated in this study. This thesis had not been possible without you.

Peter Strålfors and his research team for all help with the adipocyte project.

All administrative and technical personnel, Chatarina Malm, Annett Wiklund, Annelie Munther, Gunilla Linghammar, Håkan Wiktander, Bibbi Mårdh, Karin Söderman, and Pia Karlsson, for being patient with my questions and solving my problems!

Elin Karlsson for being my friend, for sharing both ups and downs in the lab, for always giving good advice and always being such a support! I miss you!

My former roommates, Eva Hellqvist, Ann-Charlotta Bergh, Emelie Severinsson, and Susanne Svensson for putting up with me and for your kindness and support during my years as a PhD student.

Members of the oncology groups; Agneta, Alessandra, Camilla, Cynthia, Erik, Gizeh, Helena, Jie, Josefine, Linda, Mo-Jin, Na, Olle, Sebastian, Stéphanie, Xiao-Feng, Lisa, Zeljana, and Tove for all the interesting discussions during the oncology seminars and journal clubs, and for all the nice talks in the lunch room during coffee breaks.

All researchers and staff at KEF and LRM for making me feel welcome when I first arrived to $\mathrm{KEF}$ and for the nice company during coffee breaks and lunches. 
Former colleagues at the division of Cell Biology floor 13; Anders, Anita L, Anita S, Anna G, Anna L-M, Annelie, Brigitta, Chamilly, Christine, Cilla, Emelie, Eva, Hanna, Ingmar, Jacob, Kerstin, Lotta, Maria, Narges, Sara, Susana, and Viviana for all the nice talk during coffee breaks and for always caring for me and having time to listen to me whenever I have needed. Special thanks to Anders Rosén and all members of your research team for welcoming me in your lab for more than 2 years. I have learned so much about B-cells, CLL, antibodies, and about myself.

The people at Campus Valla; special thanks to Maria Sunnerhagen, for introducing me to science and for giving me the opportunity to do my master's dissertation in your lab. Cecilia Andrésen, former supervisor and friend, for your kindness and help during my time at Valla.

Last but not least, to my dear family: my mother and father, sisters and brothers, uncles and aunts, cousins and friends!

My mother and father, Seham and Jakob, for always being there and for your endless love, help and support over the years. You are the best parents one could ever wish for!

My siblings Lona, Vanda, Morad, and Hend, and all of your husbands/wife, and also my little brother Gabriel, for always being supportive and encouraging me throughout my life. Thank you for your kindness and endless love. You are the best! Special thanks to my nieces and nephews for all the fun and happiness you bring. I love you all!

This work was kindly supported by grants from the Swedish Cancer Society, the Swedish Research Council, and the Research Funds of Linköping University. 


\section{References}

1. Hanahan D, Weinberg RA. Hallmarks of cancer: the next generation. Cell. 2011;144(5):646-74.

2. Anand $P$, Kunnumakkara AB, Sundaram C, Harikumar KB, Tharakan ST, Lai OS, et al. Cancer is a preventable disease that requires major lifestyle changes. Pharmaceutical research. 2008;25(9):2097-116.

3. Croce CM. Oncogenes and cancer. The New England journal of medicine. 2008;358(5):502-11.

4. Merlo LM, Pepper JW, Reid BJ, Maley CC. Cancer as an evolutionary and ecological process. Nature reviews Cancer. 2006;6(12):924-35.

5. Ferlay J, Steliarova-Foucher E, Lortet-Tieulent J, Rosso S, Coebergh JW, Comber H, et al. Cancer incidence and mortality patterns in Europe: estimates for 40 countries in 2012. European journal of cancer. 2013;49(6):1374-403.

6. Stewart BW, Wild C. World cancer report 2014: World Health Organization; 2014.

$7 . \quad \mathrm{Li} \mathrm{Cl}$. Risk of mortality by histologic type of breast cancer in the United States. Hormones \& cancer. 2010;1(3):156-65.

8. $\quad$ Adlercreutz H. Phytoestrogens and breast cancer. The Journal of steroid biochemistry and molecular biology. 2002;83(1-5):113-8.

9. Beral V, Million Women Study C. Breast cancer and hormone-replacement therapy in the Million Women Study. Lancet. 2003;362(9382):419-27.

10. Hulka BS, Stark AT. Breast cancer: cause and prevention. Lancet. 1995;346(8979):883-

7.

11. Kelsey JL, Gammon MD, John EM. Reproductive factors and breast cancer. Epidemiologic reviews. 1993;15(1):36-47.

12. MacMahon B, Cole P, Lin TM, Lowe CR, Mirra AP, Ravnihar B, et al. Age at first birth and breast cancer risk. Bulletin of the World Health Organization. 1970;43(2):209-21.

13. Gage M, Wattendorf D, Henry LR. Translational advances regarding hereditary breast cancer syndromes. Journal of surgical oncology. 2012;105(5):444-51.

14. Warner E. Clinical practice. Breast-cancer screening. The New England journal of medicine. 2011;365(11):1025-32.

15. Goldhirsch A, Ingle JN, Gelber RD, Coates AS, Thurlimann B, Senn HJ, et al. Thresholds for therapies: highlights of the St Gallen International Expert Consensus on the primary therapy of early breast cancer 2009. Annals of oncology : official journal of the European Society for Medical Oncology / ESMO. 2009;20(8):1319-29.

16. Molina R, Barak V, van Dalen A, Duffy MJ, Einarsson R, Gion M, et al. Tumor markers in breast cancer- European Group on Tumor Markers recommendations. Tumour biology : the journal of the International Society for Oncodevelopmental Biology and Medicine. 2005;26(6):28193.

17. Group EBCTC. Relevance of breast cancer hormone receptors and other factors to the efficacy of adjuvant tamoxifen: patient-level meta-analysis of randomised trials. The lancet. 2011;378(9793):771-84.

18. $\quad$ SB Sbcg. National guidelines for treating breast cancer 20132013.

19. Edge SB, Compton CC. The American Joint Committee on Cancer: the 7th edition of the AJCC cancer staging manual and the future of TNM. Annals of surgical oncology. 2010;17(6):1471-4.

20. Liljegren G, Holmberg L, Bergh J, Lindgren A, Tabar L, Nordgren H, et al. 10-Year results after sector resection with or without postoperative radiotherapy for stage I breast cancer: a randomized trial. Journal of clinical oncology : official journal of the American Society of Clinical Oncology. 1999;17(8):2326-33. 

al. Breast conservation surgery, with and without radiotherapy, in women with lymph node-negative breast cancer: a randomised clinical trial in a population with access to public mammography screening. European journal of cancer. 2003;39(12):1690-7.

22. Veronesi U, Cascinelli N, Mariani L, Greco M, Saccozzi R, Luini A, et al. Twenty-year follow-up of a randomized study comparing breast-conserving surgery with radical mastectomy for early breast cancer. The New England journal of medicine. 2002;347(16):1227-32.

23. Group EBCTC. Effect of radiotherapy after breast-conserving surgery on 10-year recurrence and 15-year breast cancer death: meta-analysis of individual patient data for 10801 women in 17 randomised trials. Lancet. 2011;378(9804):1707.

24. Clarke M, Collins R, Darby S, Davies C, Elphinstone P, Evans E, et al. Effects of radiotherapy and of differences in the extent of surgery for early breast cancer on local recurrence and 15-year survival: an overview of the randomised trials. Lancet. 2005;366(9503):2087-106.

25. Davies C, Pan H, Godwin J, Gray R, Arriagada R, Raina V, et al. Long-term effects of continuing adjuvant tamoxifen to 10 years versus stopping at 5 years after diagnosis of oestrogen receptor-positive breast cancer: ATLAS, a randomised trial. Lancet. 2013;381(9869):805-16.

26. CTSU RI. Effects of chemotherapy and hormonal therapy for early breast cancer on recurrence and 15-year survival: an overview of the randomised trials. Lancet. 2005;365:1687-717.

27. Group EBCTC. Adjuvant chemotherapy in oestrogen-receptor-poor breast cancer: patient-level meta-analysis of randomised trials. The Lancet. 2008;371(9606):29-40.

28. Russo J, Russo IH. Development of the human breast. Maturitas. 2004;49(1):2-15.

29. Macias H, Hinck L. Mammary gland development. Wiley interdisciplinary reviews Developmental biology. 2012;1(4):533-57.

30. Russo J, Mailo D, Hu YF, Balogh G, Sheriff F, Russo IH. Breast differentiation and its implication in cancer prevention. Clinical cancer research : an official journal of the American Association for Cancer Research. 2005;11(2 Pt 2):931s-6s.

31. Veronesi U, Boyle P, Goldhirsch A, Orecchia R, Viale G. Breast cancer. Lancet. 2005;365(9472):1727-41.

32. Russo J, Russo $\mathrm{IH}$. Breast development, hormones and cancer. Advances in experimental medicine and biology. 2008;630:52-6.

33. Edwards DP. Regulation of signal transduction pathways by estrogen and progesterone. Annual review of physiology. 2005;67:335-76.

34. Nelson LR, Bulun SE. Estrogen production and action. Journal of the American Academy of Dermatology. 2001;45(3 Suppl):S116-24.

35. Cui J, Shen Y, Li R. Estrogen synthesis and signaling pathways during aging: from periphery to brain. Trends in molecular medicine. 2013;19(3):197-209.

36. Bjornstrom L, Sjoberg M. Estrogen receptor-dependent activation of AP-1 via nongenomic signalling. Nuclear receptor. 2004;2(1):3.

37. Zivadinovic D, Gametchu B, Watson CS. Membrane estrogen receptor-alpha levels in MCF-7 breast cancer cells predict CAMP and proliferation responses. Breast cancer research : BCR. 2005;7(1):R101-12.

38. Zivadinovic $D$, Watson CS. Membrane estrogen receptor-alpha levels predict estrogeninduced ERK1/2 activation in MCF-7 cells. Breast cancer research : BCR. 2005;7(1):R130-44.

39. Matthews J, Gustafsson JA. Estrogen signaling: a subtle balance between ER alpha and ER beta. Molecular interventions. 2003;3(5):281-92.

40. Khan SA, Rogers MA, Obando JA, Tamsen A. Estrogen receptor expression of benign breast epithelium and its association with breast cancer. Cancer research. 1994;54(4):993-7.

41. Yager JD, Davidson NE. Estrogen carcinogenesis in breast cancer. The New England journal of medicine. 2006;354(3):270-82.

42. Anderson E, Clarke RB, Howell A. Estrogen responsiveness and control of normal human breast proliferation. Journal of mammary gland biology and neoplasia. 1998;3(1):23-35. 

Risks and benefits of estrogen plus progestin in healthy postmenopausal women: principal results From the Women's Health Initiative randomized controlled trial. JAMA : the journal of the American Medical Association. 2002;288(3):321-33.

44. Beatson G. ON THE TREATMENT OF INOPERABLE CASES OF CARCINOMA OF THE MAMMA: SUGGESTIONS FOR A NEW METHOD OF TREATMENT, WITH ILLUSTRATIVE CASES. The Lancet. 1896;148(3803):162-5.

45. Lambe M, Hsieh CC, Chan HW, Ekbom A, Trichopoulos D, Adami HO. Parity, age at first and last birth, and risk of breast cancer: a population-based study in Sweden. Breast cancer research and treatment. 1996;38(3):305-11.

46. Endogenous H, Breast Cancer Collaborative G, Key TJ, Appleby PN, Reeves GK, Roddam AW, et al. Circulating sex hormones and breast cancer risk factors in postmenopausal women: reanalysis of 13 studies. British journal of cancer. 2011;105(5):709-22.

47. Endogenous H, Breast Cancer Collaborative G, Key TJ, Appleby PN, Reeves GK, Travis $\mathrm{RC}$, et al. Sex hormones and risk of breast cancer in premenopausal women: a collaborative reanalysis of individual participant data from seven prospective studies. The Lancet Oncology. 2013;14(10):1009-19.

48. Chetrite GS, Cortes-Prieto J, Philippe JC, Wright F, Pasqualini JR. Comparison of estrogen concentrations, estrone sulfatase and aromatase activities in normal, and in cancerous, human breast tissues. The Journal of steroid biochemistry and molecular biology. 2000;72(1-2):23-7.

49. Pasqualini JR, Cortes-Prieto J, Chetrite G, Talbi M, Ruiz A. Concentrations of estrone, estradiol and their sulfates, and evaluation of sulfatase and aromatase activities in patients with breast fibroadenoma. International journal of cancer Journal international du cancer. 1997;70(6):639-43.

50. van Landeghem AA, Poortman J, Nabuurs M, Thijssen JH. Endogenous concentration and subcellular distribution of estrogens in normal and malignant human breast tissue. Cancer research. 1985;45(6):2900-6.

51. Cuzick J, Forbes J, Edwards R, Baum M, Cawthorn S, Coates A, et al. First results from the International Breast Cancer Intervention Study (IBIS-I): a randomised prevention trial. Lancet. 2002;360(9336):817-24.

52. Cuzick J, Powles T, Veronesi U, Forbes J, Edwards R, Ashley S, et al. Overview of the main outcomes in breast-cancer prevention trials. Lancet. 2003;361(9354):296-300.

53. Blok EJ, Derks MG, van der Hoeven JJ, van de Velde CJ, Kroep JR. Extended adjuvant endocrine therapy in hormone-receptor positive early breast cancer: Current and future evidence. Cancer treatment reviews. 2015;41(3):271-6.

54. Haddad TC, Goetz MP. Landscape of Neoadjuvant Therapy for Breast Cancer. Annals of surgical oncology. 2015.

55. Cuzick J, Sestak I, Baum M, Buzdar A, Howell A, Dowsett M, et al. Effect of anastrozole and tamoxifen as adjuvant treatment for early-stage breast cancer: 10-year analysis of the ATAC trial. The Lancet Oncology. 2010;11(12):1135-41.

56. Dowsett M, Cuzick J, Ingle J, Coates A, Forbes J, Bliss J, et al. Meta-analysis of breast cancer outcomes in adjuvant trials of aromatase inhibitors versus tamoxifen. Journal of clinical oncology : official journal of the American Society of Clinical Oncology. 2010;28(3):509-18.

57. Lim YC, Desta Z, Flockhart DA, Skaar TC. Endoxifen (4-hydroxy-N-desmethyltamoxifen) has anti-estrogenic effects in breast cancer cells with potency similar to 4-hydroxytamoxifen. Cancer chemotherapy and pharmacology. 2005;55(5):471-8.

58. Lim YC, Li L, Desta Z, Zhao Q, Rae JM, Flockhart DA, et al. Endoxifen, a secondary metabolite of tamoxifen, and 4-OH-tamoxifen induce similar changes in global gene expression patterns in MCF-7 breast cancer cells. The Journal of pharmacology and experimental therapeutics. 2006;318(2):503-12. 
59. Robinson E, Kimmick GG, Muss HB. Tamoxifen in postmenopausal women a safety perspective. Drugs \& aging. 1996;8(5):329-37.

60. Bernstein L, Deapen D, Cerhan JR, Schwartz SM, Liff J, McGann-Maloney E, et al. Tamoxifen therapy for breast cancer and endometrial cancer risk. Journal of the National Cancer Institute. 1999;91(19):1654-62.

61. Fisher B, Costantino JP, Wickerham DL, Cecchini RS, Cronin WM, Robidoux A, et al. Tamoxifen for the prevention of breast cancer: current status of the National Surgical Adjuvant Breast and Bowel Project P-1 study. Journal of the National Cancer Institute. 2005;97(22):1652-62.

62. Group BIGC, Mouridsen H, Giobbie-Hurder A, Goldhirsch A, Thurlimann B, Paridaens $\mathrm{R}$, et al. Letrozole therapy alone or in sequence with tamoxifen in women with breast cancer. The New England journal of medicine. 2009;361(8):766-76.

63. Jordan VC. Tamoxifen $(\mathrm{ICI} 46,474)$ as a targeted therapy to treat and prevent breast cancer. British journal of pharmacology. 2006;147 Suppl 1:S269-76.

64. Randomized trial of two versus five years of adjuvant tamoxifen for postmenopausal early stage breast cancer. Swedish Breast Cancer Cooperative Group. Journal of the National Cancer Institute. 1996;88(21):1543-9.

65. Ferno M, Stal O, Baldetorp B, Hatschek T, Kallstrom AC, Malmstrom P, et al. Results of two or five years of adjuvant tamoxifen correlated to steroid receptor and S-phase levels. South Sweden Breast Cancer Group, and South-East Sweden Breast Cancer Group. Breast cancer research and treatment. 2000;59(1):69-76.

66. Kansra S, Yamagata S, Sneade L, Foster L, Ben-Jonathan N. Differential effects of estrogen receptor antagonists on pituitary lactotroph proliferation and prolactin release. Molecular and cellular endocrinology. 2005;239(1-2):27-36.

67. McKeage K, Curran MP, Plosker GL. Fulvestrant: a review of its use in hormone receptor-positive metastatic breast cancer in postmenopausal women with disease progression following antiestrogen therapy. Drugs. 2004;64(6):633-48.

68. Croxtall JD, McKeage K. Fulvestrant: a review of its use in the management of hormone receptor-positive metastatic breast cancer in postmenopausal women. Drugs. 2011;71(3):363-80.

69. Swartz MA, lida N, Roberts EW, Sangaletti S, Wong MH, Yull FE, et al. Tumor microenvironment complexity: emerging roles in cancer therapy. Cancer research. 2012;72(10):2473-80.

70. Pollard JW. Tumour-educated macrophages promote tumour progression and metastasis. Nature reviews Cancer. 2004;4(1):71-8.

71. Sund M, Kalluri R. Tumor stroma derived biomarkers in cancer. Cancer metastasis reviews. 2009;28(1-2):177-83.

72. Ouchi N, Parker JL, Lugus JJ, Walsh K. Adipokines in inflammation and metabolic disease. Nature reviews Immunology. 2011;11(2):85-97.

73. Philip $M$, Rowley DA, Schreiber $H$. Inflammation as a tumor promoter in cancer induction. Seminars in cancer biology. 2004;14(6):433-9.

74. Balkwill F, Mantovani A. Inflammation and cancer: back to Virchow? Lancet. 2001;357(9255):539-45.

75. Harris RE, Beebe-Donk J, Doss H, Burr Doss D. Aspirin, ibuprofen, and other nonsteroidal anti-inflammatory drugs in cancer prevention: a critical review of non-selective COX-2 blockade (review). Oncology reports. 2005;13(4):559-83.

76. Ernst PB, Gold BD. The disease spectrum of Helicobacter pylori: the immunopathogenesis of gastroduodenal ulcer and gastric cancer. Annual review of microbiology. 2000;54:615-40.

77. Triantafillidis JK, Nasioulas G, Kosmidis PA. Colorectal cancer and inflammatory bowel disease: epidemiology, risk factors, mechanisms of carcinogenesis and prevention strategies. Anticancer research. 2009;29(7):2727-37. 

or foes? Clinical \& experimental metastasis. 2002;19(3):247-58.

79. Coussens LM, Werb Z. Inflammation and cancer. Nature. 2002;420(6917):860-7.

80. Leek RD, Harris AL. Tumor-associated macrophages in breast cancer. Journal of mammary gland biology and neoplasia. 2002;7(2):177-89.

81. Kelly PM, Davison RS, Bliss E, McGee JO. Macrophages in human breast disease: a quantitative immunohistochemical study. British journal of cancer. 1988;57(2):174-7.

82. Lewis CE, Pollard JW. Distinct role of macrophages in different tumor microenvironments. Cancer research. 2006;66(2):605-12.

83. Solinas G, Germano G, Mantovani A, Allavena P. Tumor-associated macrophages (TAM) as major players of the cancer-related inflammation. Journal of leukocyte biology. 2009;86(5):1065-73.

84. Lin EY, Pollard JW. Tumor-associated macrophages press the angiogenic switch in breast cancer. Cancer research. 2007;67(11):5064-6.

85. Lewis CE, Hughes R. Inflammation and breast cancer. Microenvironmental factors regulating macrophage function in breast tumours: hypoxia and angiopoietin-2. Breast cancer research : BCR. 2007;9(3):209.

86. Luo Y, Zhou H, Krueger J, Kaplan C, Lee SH, Dolman C, et al. Targeting tumorassociated macrophages as a novel strategy against breast cancer. J Clin Invest. 2006;116(8):213241.

87. Wu W, Luo Y, Sun C, Liu Y, Kuo P, Varga J, et al. Targeting cell-impermeable prodrug activation to tumor microenvironment eradicates multiple drug-resistant neoplasms. Cancer research. 2006;66(2):970-80.

88. Zamarron BF, Chen W. Dual roles of immune cells and their factors in cancer development and progression. International journal of biological sciences. 2011;7(5):651-8.

89. Dranoff G. Cytokines in cancer pathogenesis and cancer therapy. Nature reviews Cancer. 2004;4(1):11-22.

90. Lippman M, Bolan G, Huff K. The effects of estrogens and antiestrogens on hormoneresponsive human breast cancer in long-term tissue culture. Cancer research. 1976;36(12):4595-601. 91. Nicolini A, Carpi A, Rossi G. Cytokines in breast cancer. Cytokine \& growth factor reviews. 2006;17(5):325-37.

92. Apte RN, Krelin $Y$, Song $X$, Dotan $S$, Recih E, Elkabets $M$, et al. Effects of microenvironment- and malignant cell-derived interleukin-1 in carcinogenesis, tumour invasiveness and tumour-host interactions. European journal of cancer. 2006;42(6):751-9.

93. Dinarello CA. Immunological and inflammatory functions of the interleukin-1 family. Annual review of immunology. 2009;27:519-50.

94. Voronov E, Shouval DS, Krelin Y, Cagnano E, Benharroch D, Iwakura Y, et al. IL-1 is required for tumor invasiveness and angiogenesis. Proceedings of the National Academy of Sciences of the United States of America. 2003;100(5):2645-50.

95. Dinarello CA. Interleukin-1, interleukin-1 receptors and interleukin-1 receptor antagonist. International reviews of immunology. 1998;16(5-6):457-99.

96. Weber A, Wasiliew P, Kracht M. Interleukin-1 (IL-1) pathway. Science signaling. 2010;3(105):cm1.

97. Sims JE, Gayle MA, Slack JL, Alderson MR, Bird TA, Giri JG, et al. Interleukin 1 signaling occurs exclusively via the type I receptor. Proceedings of the National Academy of Sciences of the United States of America. 1993;90(13):6155-9.

98. Boraschi D, Tagliabue A. The interleukin-1 receptor family. Vitamins and hormones. 2006;74:229-54.

99. Dinarello CA. Biologic basis for interleukin-1 in disease. Blood. 1996;87(6):2095-147.

100. Dinarello CA. Blocking interleukin-1beta in acute and chronic autoinflammatory diseases. Journal of internal medicine. 2011;269(1):16-28. 

al. Critical role for NALP3/CIAS1/Cryopyrin in innate and adaptive immunity through its regulation of caspase-1. Immunity. 2006;24(3):317-27.

102. Wessendorf JH, Garfinkel S, Zhan X, Brown S, Maciag T. Identification of a nuclear localization sequence within the structure of the human interleukin-1 alpha precursor. The Journal of biological chemistry. 1993;268(29):22100-4.

103. Arend WP, Malyak M, Guthridge CJ, Gabay C. Interleukin-1 receptor antagonist: role in biology. Annual review of immunology. 1998;16:27-55.

104. Waugh J, Perry CM. Anakinra: a review of its use in the management of rheumatoid arthritis. BioDrugs : clinical immunotherapeutics, biopharmaceuticals and gene therapy. 2005;19(3):189-202.

105. Larsen CM, Faulenbach M, Vaag A, Volund A, Ehses JA, Seifert B, et al. Interleukin-1receptor antagonist in type 2 diabetes mellitus. The New England journal of medicine. 2007;356(15):1517-26.

106. Lewis AM, Varghese S, Xu H, Alexander HR. Interleukin-1 and cancer progression: the emerging role of interleukin-1 receptor antagonist as a novel therapeutic agent in cancer treatment. Journal of translational medicine. 2006;4:48.

107. Chavey C, Bibeau F, Gourgou-Bourgade S, Burlinchon S, Boissiere F, Laune D, et al. Oestrogen receptor negative breast cancers exhibit high cytokine content. Breast cancer research : BCR. 2007;9(1):R15.

108. Pantschenko AG, Pushkar I, Anderson KH, Wang Y, Miller L, Kurtzman SH, et al. The interleukin-1 family of cytokines and receptors in human breast cancer: implications for tumor progression. International journal of oncology. 2003;23(2):269-84.

109. Liu L, Gudas L. Retinoic acid induces expression of the interleukin-1beta gene in cultured normal human mammary epithelial cells and in human breast carcinoma lines. Journal of cellular physiology. 2002;193(2):244-52.

110. Fischer-Posovszky P, Wabitsch M, Hochberg Z. Endocrinology of adipose tissue - an update. Hormone and metabolic research $=$ Hormon- und Stoffwechselforschung $=$ Hormones et metabolisme. 2007;39(5):314-21.

111. Kershaw EE, Flier JS. Adipose tissue as an endocrine organ. The Journal of clinical endocrinology and metabolism. 2004;89(6):2548-56.

112. Ahima RS, Flier JS. Adipose tissue as an endocrine organ. Trends in endocrinology and metabolism: TEM. 2000;11(8):327-32.

113. Conde J, Scotece M, Gomez R, Lopez V, Gomez-Reino JJ, Lago F, et al. Adipokines: biofactors from white adipose tissue. A complex hub among inflammation, metabolism, and immunity. BioFactors. 2011;37(6):413-20.

114. Lehr S, Hartwig S, Sell H. Adipokines: a treasure trove for the discovery of biomarkers for metabolic disorders. Proteomics Clinical applications. 2012;6(1-2):91-101.

115. Zhang F, Chen Y, Heiman M, Dimarchi R. Leptin: structure, function and biology. Vitamins and hormones. 2005;71:345-72.

116. Fantuzzi G, Faggioni R. Leptin in the regulation of immunity, inflammation, and hematopoiesis. Journal of leukocyte biology. 2000;68(4):437-46.

117. Halaas JL, Gajiwala KS, Maffei M, Cohen SL, Chait BT, Rabinowitz D, et al. Weightreducing effects of the plasma protein encoded by the obese gene. Science. 1995;269(5223):543-6.

118. Harigaya A, Nagashima K, Nako Y, Morikawa A. Relationship between concentration of serum leptin and fetal growth. The Journal of clinical endocrinology and metabolism. 1997;82(10):3281-4.

119. Williams KW, Scott MM, Elmquist JK. From observation to experimentation: leptin action in the mediobasal hypothalamus. The American journal of clinical nutrition. 2009;89(3):985S$90 \mathrm{~S}$.

120. Vogel G. Leptin: a trigger for puberty? Science. 1996;274(5292):1466-7. 
121. Bouloumie A, Drexler HC, Lafontan M, Busse R. Leptin, the product of Ob gene, promotes angiogenesis. Circulation research. 1998;83(10):1059-66.

122. Ducy $P$, Amling M, Takeda S, Priemel M, Schilling AF, Beil FT, et al. Leptin inhibits bone formation through a hypothalamic relay: a central control of bone mass. Cell. 2000;100(2):197-207.

123. Sierra-Honigmann MR, Nath AK, Murakami C, Garcia-Cardena G, Papapetropoulos A, Sessa WC, et al. Biological action of leptin as an angiogenic factor. Science. 1998;281(5383):1683-6.

124. Bjorbaek C, Uotani S, da Silva B, Flier JS. Divergent signaling capacities of the long and short isoforms of the leptin receptor. The Journal of biological chemistry. 1997;272(51):32686-95.

125. Sweeney G. Leptin signalling. Cellular signalling. 2002;14(8):655-63.

126. Cirillo D, Rachiglio AM, la Montagna R, Giordano A, Normanno N. Leptin signaling in breast cancer: an overview. Journal of cellular biochemistry. 2008;105(4):956-64.

127. Ahima RS, Osei SY. Leptin signaling. Physiology \& behavior. 2004;81(2):223-41.

128. Catalano S, Marsico S, Giordano C, Mauro L, Rizza P, Panno ML, et al. Leptin enhances, via AP-1, expression of aromatase in the MCF-7 cell line. The Journal of biological chemistry. 2003;278(31):28668-76.

129. Chen C, Chang YC, Liu CL, Chang KJ, Guo IC. Leptin-induced growth of human ZR-75-1 breast cancer cells is associated with up-regulation of cyclin D1 and c-Myc and down-regulation of tumor suppressor p53 and p21WAF1/CIP1. Breast cancer research and treatment. 2006;98(2):12132.

130. Gonzalez RR, Cherfils S, Escobar M, Yoo JH, Carino C, Styer AK, et al. Leptin signaling promotes the growth of mammary tumors and increases the expression of vascular endothelial growth factor (VEGF) and its receptor type two (VEGF-R2). The Journal of biological chemistry. 2006;281(36):26320-8.

131. Ozet A, Arpaci F, Yilmaz MI, Ayta H, Ozturk B, Komurcu S, et al. Effects of tamoxifen on the serum leptin level in patients with breast cancer. Japanese journal of clinical oncology. 2001;31(9):424-7.

132. Tessitore L, Vizio B, Jenkins O, De Stefano I, Ritossa C, Argiles JM, et al. Leptin expression in colorectal and breast cancer patients. International journal of molecular medicine. 2000;5(4):421-6.

133. Harris HR, Tworoger SS, Hankinson SE, Rosner BA, Michels KB. Plasma leptin levels and risk of breast cancer in premenopausal women. Cancer prevention research. 2011;4(9):1449-56.

134. Garofalo C, Koda M, Cascio S, Sulkowska M, Kanczuga-Koda L, Golaszewska J, et al. Increased expression of leptin and the leptin receptor as a marker of breast cancer progression: possible role of obesity-related stimuli. Clinical cancer research : an official journal of the American Association for Cancer Research. 2006;12(5):1447-53.

135. Ishikawa M, Kitayama J, Nagawa H. Enhanced expression of leptin and leptin receptor (OB-R) in human breast cancer. Clinical cancer research : an official journal of the American Association for Cancer Research. 2004;10(13):4325-31.

136. Cleary MP, Juneja SC, Phillips FC, Hu X, Grande JP, Maihle NJ. Leptin receptor-deficient MMTV-TGF-alpha/Lepr(db)Lepr(db) female mice do not develop oncogene-induced mammary tumors. Experimental biology and medicine. 2004;229(2):182-93.

137. Cleary MP, Phillips FC, Getzin SC, Jacobson TL, Jacobson MK, Christensen TA, et al. Genetically obese MMTV-TGF-alpha/Lep(ob)Lep(ob) female mice do not develop mammary tumors. Breast cancer research and treatment. 2003;77(3):205-15.

138. Diez JJ, Iglesias P. The role of the novel adipocyte-derived hormone adiponectin in human disease. European journal of endocrinology / European Federation of Endocrine Societies. 2003;148(3):293-300.

139. Yamauchi T, Kamon J, Ito Y, Tsuchida A, Yokomizo T, Kita S, et al. Cloning of adiponectin receptors that mediate antidiabetic metabolic effects. Nature. 2003;423(6941):762-9. 

hexameric and high-molecular-weight forms of Acrp30/adiponectin. Proceedings of the National Academy of Sciences of the United States of America. 2004;101(28):10308-13.

141. Kadowaki T, Yamauchi T. Adiponectin and adiponectin receptors. Endocrine reviews. 2005;26(3):439-51.

142. Akifusa S, Kamio N, Shimazaki Y, Yamaguchi N, Nonaka K, Yamashita Y. Involvement of the JAK-STAT pathway and SOCS3 in the regulation of adiponectin-generated reactive oxygen species in murine macrophage RAW 264 cells. Journal of cellular biochemistry. 2010;111(3):597-606.

143. Bjursell M, Ahnmark A, Bohlooly YM, William-Olsson L, Rhedin M, Peng XR, et al. Opposing effects of adiponectin receptors 1 and 2 on energy metabolism. Diabetes. 2007;56(3):58393.

144. Kim AY, Lee YS, Kim KH, Lee JH, Lee HK, Jang SH, et al. Adiponectin represses colon cancer cell proliferation via AdipoR1- and -R2-mediated AMPK activation. Molecular endocrinology. 2010;24(7):1441-52.

145. Yamauchi T, Nio Y, Maki T, Kobayashi M, Takazawa T, Iwabu M, et al. Targeted disruption of AdipoR1 and AdipoR2 causes abrogation of adiponectin binding and metabolic actions. Nature medicine. 2007;13(3):332-9.

146. Wang Y, Lam JB, Lam KS, Liu J, Lam MC, Hoo RL, et al. Adiponectin modulates the glycogen synthase kinase-3beta/beta-catenin signaling pathway and attenuates mammary tumorigenesis of MDA-MB-231 cells in nude mice. Cancer research. 2006;66(23):11462-70.

147. Waki H, Yamauchi T, Kamon J, Kita S, Ito Y, Hada Y, et al. Generation of globular fragment of adiponectin by leukocyte elastase secreted by monocytic cell line THP-1. Endocrinology. 2005;146(2):790-6.

148. Dalamaga M, Diakopoulos KN, Mantzoros CS. The role of adiponectin in cancer: a review of current evidence. Endocrine reviews. 2012;33(4):547-94.

149. Chen X, Wang Y. Adiponectin and breast cancer. Medical oncology. 2011;28(4):1288-

95.

150. Mantzoros C, Petridou E, Dessypris N, Chavelas C, Dalamaga M, Alexe DM, et al. Adiponectin and breast cancer risk. The Journal of clinical endocrinology and metabolism. 2004;89(3):1102-7.

151. Tworoger SS, Eliassen AH, Kelesidis T, Colditz GA, Willett WC, Mantzoros CS, et al. Plasma adiponectin concentrations and risk of incident breast cancer. The Journal of clinical endocrinology and metabolism. 2007;92(4):1510-6.

152. Dieudonne MN, Bussiere M, Dos Santos E, Leneveu MC, Giudicelli Y, Pecquery R. Adiponectin mediates antiproliferative and apoptotic responses in human MCF7 breast cancer cells. Biochemical and biophysical research communications. 2006;345(1):271-9.

153. Taliaferro-Smith L, Nagalingam A, Zhong D, Zhou W, Saxena NK, Sharma D. LKB1 is required for adiponectin-mediated modulation of AMPK-S6K axis and inhibition of migration and invasion of breast cancer cells. Oncogene. 2009;28(29):2621-33.

154. Korner A, Pazaitou-Panayiotou K, Kelesidis T, Kelesidis I, Williams CJ, Kaprara A, et al. Total and high-molecular-weight adiponectin in breast cancer: in vitro and in vivo studies. The Journal of clinical endocrinology and metabolism. 2007;92(3):1041-8.

155. Pfeiler G, Hudelist G, Wulfing P, Mattsson B, Konigsberg R, Kubista E, et al. Impact of AdipoR1 expression on breast cancer development. Gynecologic oncology. 2010;117(1):134-8.

156. Pfeiler G, Treeck O, Wenzel G, Goerse R, Hartmann A, Schmitz G, et al. Influence of insulin resistance on adiponectin receptor expression in breast cancer. Maturitas. 2009;63(3):253-6.

157. Takahata C, Miyoshi Y, Irahara N, Taguchi T, Tamaki Y, Noguchi S. Demonstration of adiponectin receptors 1 and 2 mRNA expression in human breast cancer cells. Cancer letters. 2007;250(2):229-36. 
158.

Nakayama S, Miyoshi Y, Ishihara H, Noguchi S. Growth-inhibitory effect of adiponectin via adiponectin receptor 1 on human breast cancer cells through inhibition of S-phase entry without inducing apoptosis. Breast cancer research and treatment. 2008;112(3):405-10.

159. Andreeva AV, Kutuzov MA. Cadherin 13 in cancer. Genes, chromosomes \& cancer. 2010;49(9):775-90.

160. Grossmann ME, Cleary MP. The balance between leptin and adiponectin in the control of carcinogenesis - focus on mammary tumorigenesis. Biochimie. 2012;94(10):2164-71.

161. Delort L, Jarde T, Dubois V, Vasson MP, Caldefie-Chezet F. New insights into anticarcinogenic properties of adiponectin: a potential therapeutic approach in breast cancer? Vitamins and hormones. 2012;90:397-417.

162. Taliaferro-Smith L, Nagalingam A, Knight BB, Oberlick E, Saxena NK, Sharma D. Integral role of PTP1B in adiponectin-mediated inhibition of oncogenic actions of leptin in breast carcinogenesis. Neoplasia. 2013;15(1):23-38.

163. Cleary MP, Ray A, Rogozina OP, Dogan S, Grossmann ME. Targeting the adiponectin:leptin ratio for postmenopausal breast cancer prevention. Frontiers in bioscience. 2009;1:329-57.

164. Chen DC, Chung YF, Yeh YT, Chaung HC, Kuo FC, Fu OY, et al. Serum adiponectin and leptin levels in Taiwanese breast cancer patients. Cancer letters. 2006;237(1):109-14.

165. Ollberding NJ, Kim Y, Shvetsov YB, Wilkens LR, Franke AA, Cooney RV, et al. Prediagnostic leptin, adiponectin, $\mathrm{C}$-reactive protein, and the risk of postmenopausal breast cancer. Cancer prevention research. 2013;6(3):188-95.

166. Folkman J. Angiogenesis in cancer, vascular, rheumatoid and other disease. Nature medicine. 1995;1(1):27-31.

167. Li WW, Talcott KE, Zhai AW, Kruger EA, Li VW. The role of therapeutic angiogenesis in tissue repair and regeneration. Advances in skin \& wound care. 2005;18(9):491-500; quiz 1-2.

168. Folkman J. What is the evidence that tumors are angiogenesis dependent? Journal of the National Cancer Institute. 1990;82(1):4-6.

169. Weidner N, Folkman J, Pozza F, Bevilacqua P, Allred EN, Moore DH, et al. Tumor angiogenesis: a new significant and independent prognostic indicator in early-stage breast carcinoma. Journal of the National Cancer Institute. 1992;84(24):1875-87.

170. Kerbel RS. Tumor angiogenesis. The New England journal of medicine. 2008;358(19):2039-49.

171. Welch HG, Black WC. Using autopsy series to estimate the disease "reservoir" for ductal carcinoma in situ of the breast: how much more breast cancer can we find? Annals of internal medicine. 1997;127(11):1023-8.

172. Demicheli R, Terenziani M, Valagussa P, Moliterni A, Zambetti M, Bonadonna G. Local recurrences following mastectomy: support for the concept of tumor dormancy. Journal of the National Cancer Institute. 1994;86(1):45-8.

173. Udagawa T, Fernandez A, Achilles EG, Folkman J, D'Amato RJ. Persistence of microscopic human cancers in mice: alterations in the angiogenic balance accompanies loss of tumor dormancy. FASEB journal : official publication of the Federation of American Societies for Experimental Biology. 2002;16(11):1361-70.

174. Folkman J, Klagsbrun M. Angiogenic factors. Science. 1987;235(4787):442-7.

175. Ribatti D. Endogenous inhibitors of angiogenesis: a historical review. Leukemia research. 2009;33(5):638-44.

176. Watnick RS, Cheng YN, Rangarajan A, Ince TA, Weinberg RA. Ras modulates Myc activity to repress thrombospondin-1 expression and increase tumor angiogenesis. Cancer cell. 2003;3(3):219-31.

177. Ferrara N, Gerber HP. The role of vascular endothelial growth factor in angiogenesis. Acta haematologica. 2001;106(4):148-56. 

Vascular endothelial growth factor and angiogenesis. Pharmacological reviews. 2004;56(4):549-80.

179. Ferrara N, Davis-Smyth T. The biology of vascular endothelial growth factor. Endocrine reviews. 1997;18(1):4-25.

180. Neufeld G, Cohen T, Gengrinovitch S, Poltorak Z. Vascular endothelial growth factor (VEGF) and its receptors. FASEB journal : official publication of the Federation of American Societies for Experimental Biology. 1999;13(1):9-22.

181. Yamazaki Y, Morita T. Molecular and functional diversity of vascular endothelial growth factors. Molecular diversity. 2006;10(4):515-27.

182. Salven P, Perhoniemi V, Tykka H, Maenpaa H, Joensuu H. Serum VEGF levels in women with a benign breast tumor or breast cancer. Breast cancer research and treatment. 1999;53(2):1616.

183. Yamamoto $\mathrm{Y}$, Toi $M$, Kondo $S$, Matsumoto $T$, Suzuki $H$, Kitamura $M$, et al. Concentrations of vascular endothelial growth factor in the sera of normal controls and cancer patients. Clinical cancer research : an official journal of the American Association for Cancer Research. 1996;2(5):821-6.

184. Banks RE, Forbes MA, Kinsey SE, Stanley A, Ingham E, Walters C, et al. Release of the angiogenic cytokine vascular endothelial growth factor (VEGF) from platelets: significance for VEGF measurements and cancer biology. British journal of cancer. 1998;77(6):956-64.

185. Webb NJ, Bottomley MJ, Watson CJ, Brenchley PE. Vascular endothelial growth factor (VEGF) is released from platelets during blood clotting: implications for measurement of circulating VEGF levels in clinical disease. Clinical science. 1998;94(4):395-404.

186. Linderholm B, Grankvist K, Wilking N, Johansson M, Tavelin B, Henriksson R. Correlation of vascular endothelial growth factor content with recurrences, survival, and first relapse site in primary node-positive breast carcinoma after adjuvant treatment. Journal of clinical oncology : official journal of the American Society of Clinical Oncology. 2000;18(7):1423-31.

187. Linderholm B, Tavelin B, Grankvist K, Henriksson R. Vascular endothelial growth factor is of high prognostic value in node-negative breast carcinoma. Journal of clinical oncology : official journal of the American Society of Clinical Oncology. 1998;16(9):3121-8.

188. Dabrosin C. Positive correlation between estradiol and vascular endothelial growth factor but not fibroblast growth factor-2 in normal human breast tissue in vivo. Clinical cancer research : an official journal of the American Association for Cancer Research. 2005;11(22):8036-41.

189. Dabrosin C. Variability of vascular endothelial growth factor in normal human breast tissue in vivo during the menstrual cycle. The Journal of clinical endocrinology and metabolism. 2003;88(6):2695-8.

190. Eppenberger U, Kueng W, Schlaeppi JM, Roesel JL, Benz C, Mueller H, et al. Markers of tumor angiogenesis and proteolysis independently define high- and low-risk subsets of nodenegative breast cancer patients. Journal of clinical oncology : official journal of the American Society of Clinical Oncology. 1998;16(9):3129-36.

191. Howe GR, Hirohata T, Hislop TG, Iscovich JM, Yuan JM, Katsouyanni K, et al. Dietary factors and risk of breast cancer: combined analysis of 12 case-control studies. Journal of the National Cancer Institute. 1990;82(7):561-9.

192. Rose DP, Boyar AP, Wynder EL. International comparisons of mortality rates for cancer of the breast, ovary, prostate, and colon, and per capita food consumption. Cancer. 1986;58(11):2363-71.

193. Key TJ, Schatzkin A, Willett WC, Allen NE, Spencer EA, Travis RC. Diet, nutrition and the prevention of cancer. Public health nutrition. 2004;7(1A):187-200.

194. de Kleijn MJ, van der Schouw YT, Wilson PW, Grobbee DE, Jacques PF. Dietary intake of phytoestrogens is associated with a favorable metabolic cardiovascular risk profile in postmenopausal U.S.women: the Framingham study. The Journal of nutrition. 2002;132(2):276-82. 
195.

Valsta LM, Kilkkinen A, Mazur W, Nurmi T, Lampi AM, Ovaskainen ML, et al. Phytooestrogen database of foods and average intake in Finland. The British journal of nutrition. 2003;89 Suppl 1:S31-8.

196. Rowland I, Faughnan M, Hoey L, Wahala K, Williamson G, Cassidy A. Bioavailability of phyto-oestrogens. The British journal of nutrition. 2003;89 Suppl 1:S45-58.

197. Borriello SP, Setchell KD, Axelson M, Lawson AM. Production and metabolism of lignans by the human faecal flora. The Journal of applied bacteriology. 1985;58(1):37-43.

198. Thompson LU, Robb P, Serraino M, Cheung F. Mammalian lignan production from various foods. Nutrition and cancer. 1991;16(1):43-52.

199. Horn-Ross PL, Hoggatt KJ, West DW, Krone MR, Stewart SL, Anton H, et al. Recent diet and breast cancer risk: the California Teachers Study (USA). Cancer causes \& control : CCC. 2002;13(5):407-15.

200. Keinan-Boker L, van Der Schouw YT, Grobbee DE, Peeters PH. Dietary phytoestrogens and breast cancer risk. The American journal of clinical nutrition. 2004;79(2):282-8.

201. McCann SE, Thompson LU, Nie J, Dorn J, Trevisan M, Shields PG, et al. Dietary lignan intakes in relation to survival among women with breast cancer: the Western New York Exposures and Breast Cancer (WEB) Study. Breast cancer research and treatment. 2010;122(1):229-35.

202. Thompson LU, Chen JM, Li T, Strasser-Weippl K, Goss PE. Dietary flaxseed alters tumor biological markers in postmenopausal breast cancer. Clinical cancer research : an official journal of the American Association for Cancer Research. 2005;11(10):3828-35.

203. Thompson LU, Rickard SE, Orcheson L, Seidl MM. Flaxseed and its lignan and oil components reduce mammary tumor growth at a late stage of carcinogenesis. Carcinogenesis. 1996;17(6):1373-6.

204. Adlercreutz H. Phyto-oestrogens and cancer. The Lancet Oncology. 2002;3(6):364-73.

205. Zamora-Ros R, Ferrari P, Gonzalez CA, Tjonneland A, Olsen A, Bredsdorff L, et al. Dietary flavonoid and lignan intake and breast cancer risk according to menopause and hormone receptor status in the European Prospective Investigation into Cancer and Nutrition (EPIC) Study. Breast cancer research and treatment. 2013;139(1):163-76.

206. van Staveren WC, Solis DY, Hebrant A, Detours V, Dumont JE, Maenhaut C. Human cancer cell lines: Experimental models for cancer cells in situ? For cancer stem cells? Biochimica et biophysica acta. 2009;1795(2):92-103.

207. Hughes P, Marshall D, Reid Y, Parkes H, Gelber $C$. The costs of using unauthenticated, over-passaged cell lines: how much more data do we need? BioTechniques. 2007;43(5):575, 7-8, 812 passim.

208. Schweppe RE, Klopper JP, Korch C, Pugazhenthi U, Benezra M, Knauf JA, et al. Deoxyribonucleic acid profiling analysis of 40 human thyroid cancer cell lines reveals crosscontamination resulting in cell line redundancy and misidentification. The Journal of clinical endocrinology and metabolism. 2008;93(11):4331-41.

209. Young L, Sung J, Stacey G, Masters JR. Detection of Mycoplasma in cell cultures. Nature protocols. 2010;5(5):929-34.

210. Soule HD, Vazguez J, Long A, Albert S, Brennan M. A human cell line from a pleural effusion derived from a breast carcinoma. Journal of the National Cancer Institute. 1973;51(5):140916.

211. Lacroix M, Leclercq G. Relevance of breast cancer cell lines as models for breast tumours: an update. Breast cancer research and treatment. 2004;83(3):249-89.

212. Freshney RI. Culture of animal cells: a manual of basic technique. Wiley, New York1994.

213. Degawa-Yamauchi M, Moss KA, Bovenkerk JE, Shankar SS, Morrison CL, Lelliott CJ, et al. Regulation of adiponectin expression in human adipocytes: effects of adiposity, glucocorticoids, and tumor necrosis factor alpha. Obesity research. 2005;13(4):662-9. 
214.

Halleux CM, Takahashi M, Delporte ML, Detry R, Funahashi T, Matsuzawa $Y$, et al. Secretion of adiponectin and regulation of apM1 gene expression in human visceral adipose tissue. Biochemical and biophysical research communications. 2001;288(5):1102-7.

215. Zhang HH, Kumar S, Barnett AH, Eggo MC. Ceiling culture of mature human adipocytes: use in studies of adipocyte functions. The Journal of endocrinology. 2000;164(2):119-28.

216. Goldberg AM, Hartung T. Protecting more than animals. Scientific American. 2006;294(1):84-91.

217. Zurlo J, Rudacille D, Goldberg AM. Animals and alternatives in testing: History, science, and ethics: Mary Ann Liebert; 1994.

218. Garvin S, Nilsson UW, Huss FR, Kratz G, Dabrosin C. Estradiol increases VEGF in human breast studied by whole-tissue culture. Cell and tissue research. 2006;325(2):245-51.

219. Ungerstedt U. Microdialysis--principles and applications for studies in animals and man. Journal of internal medicine. 1991;230(4):365-73.

220. Plock N, Kloft C. Microdialysis--theoretical background and recent implementation in applied life-sciences. European journal of pharmaceutical sciences : official journal of the European Federation for Pharmaceutical Sciences. 2005;25(1):1-24.

221. Samuelsson A, Steinvall I, Sjoberg F. Microdialysis shows metabolic effects in skin during fluid resuscitation in burn-injured patients. Critical care. 2006;10(6):R172.

222. Farnebo S, Samuelsson A, Henriksson J, Karlander LE, Sjoberg F. Urea clearance: a new method to register local changes in blood flow in rat skeletal muscle based on microdialysis. Clinical physiology and functional imaging. 2010;30(1):57-63.

223. Dabrosin C, Hallstrom A, Ungerstedt U, Hammar M. Microdialysis of human breast tissue during the menstrual cycle. Clinical science. 1997;92(5):493-6.

224. Dabrosin C, Margetts PJ, Gauldie J. Estradiol increases extracellular levels of vascular endothelial growth factor in vivo in murine mammary cancer. International journal of cancer Journal international du cancer. 2003;107(4):535-40.

225. Garvin S, Dabrosin C. Tamoxifen inhibits secretion of vascular endothelial growth factor in breast cancer in vivo. Cancer research. 2003;63(24):8742-8.

226. Garvin S, Dabrosin C. In vivo measurement of tumor estradiol and vascular endothelial growth factor in breast cancer patients. BMC cancer. 2008;8:73.

227. Rosdahl H, Hamrin K, Ungerstedt U, Henriksson J. A microdialysis method for the in situ investigation of the action of large peptide molecules in human skeletal muscle: detection of local metabolic effects of insulin. International journal of biological macromolecules. 2000;28(1):6973.

228. Dahlin AP, Wetterhall M, Caldwell KD, Larsson A, Bergquist J, Hillered L, et al. Methodological aspects on microdialysis protein sampling and quantification in biological fluids: an in vitro study on human ventricular CSF. Analytical chemistry. 2010;82(11):4376-85.

229. Dankort DL, Muller WJ. Signal transduction in mammary tumorigenesis: a transgenic perspective. Oncogene. 2000;19(8):1038-44.

230. Franci C, Zhou J, Jiang Z, Modrusan Z, Good Z, Jackson E, et al. Biomarkers of residual disease, disseminated tumor cells, and metastases in the MMTV-PyMT breast cancer model. PloS one. 2013;8(3):e58183.

231. Maglione JE, Moghanaki D, Young LJ, Manner CK, Ellies LG, Joseph SO, et al. Transgenic Polyoma middle-T mice model premalignant mammary disease. Cancer research. 2001;61(22):8298-305.

232. Budzynski W, Radzikowski C. Cytotoxic cells in immunodeficient athymic mice. Immunopharmacology and immunotoxicology. 1994;16(3):319-46.

233. Cespedes MV, Casanova I, Parreno M, Mangues R. Mouse models in oncogenesis and cancer therapy. Clinical \& translational oncology : official publication of the Federation of Spanish Oncology Societies and of the National Cancer Institute of Mexico. 2006;8(5):318-29. 
234.

Clarkson TB, Appt SE, Wood CE, Cline JM. Lessons to be learned from animal studies on hormones and the breast. Maturitas. 2004;49(1):79-89.

235. Balkwill F. Tumor necrosis factor or tumor promoting factor? Cytokine \& growth factor reviews. 2002;13(2):135-41.

236. Apte RN, Voronov E. Is interleukin-1 a good or bad 'guy' in tumor immunobiology and immunotherapy? Immunological reviews. 2008;222:222-41.

237. Lindahl G, Saarinen N, Abrahamsson A, Dabrosin C. Tamoxifen, flaxseed, and the lignan enterolactone increase stroma- and cancer cell-derived IL-1Ra and decrease tumor angiogenesis in estrogen-dependent breast cancer. Cancer research. 2011;71(1):51-60.

238. Dabrosin C. Microdialysis - an in vivo technique for studies of growth factors in breast cancer. Frontiers in bioscience : a journal and virtual library. 2005;10:1329-35.

239. Dabrosin C, Ollinger K, Ungerstedt U, Hammar M. Variability of glutathione levels in normal breast tissue and subcutaneous fat during the menstrual cycle: an in vivo study with microdialysis technique. The Journal of clinical endocrinology and metabolism. 1997;82(5):1382-4.

240. Jin L, Yuan RQ, Fuchs A, Yao Y, Joseph A, Schwall R, et al. Expression of interleukin1beta in human breast carcinoma. Cancer. 1997;80(3):421-34.

241. Buck K, Vrieling A, Zaineddin AK, Becker S, Husing A, Kaaks R, et al. Serum enterolactone and prognosis of postmenopausal breast cancer. Journal of clinical oncology : official journal of the American Society of Clinical Oncology. 2011;29(28):3730-8.

242. Guglielmini P, Rubagotti A, Boccardo F. Serum enterolactone levels and mortality outcome in women with early breast cancer: a retrospective cohort study. Breast cancer research and treatment. 2012;132(2):661-8.

243. Olsen A, Christensen J, Knudsen KE, Johnsen NF, Overvad K, Tjonneland A. Prediagnostic plasma enterolactone levels and mortality among women with breast cancer. Breast cancer research and treatment. 2011;128(3):883-9.

244. Sunyer T, Lewis J, Collin-Osdoby P, Osdoby P. Estrogen's bone-protective effects may involve differential IL-1 receptor regulation in human osteoclast-like cells. J Clin Invest. 1999;103(10):1409-18.

245. Park S, Cheon S, Cho D. The dual effects of interleukin-18 in tumor progression. Cellular \& molecular immunology. 2007;4(5):329-35.

246. Palma G, Barbieri A, Bimonte S, Palla M, Zappavigna S, Caraglia M, et al. Interleukin 18: friend or foe in cancer. Biochimica et biophysica acta. 2013;1836(2):296-303.

247. Dinarello CA, Novick D, Puren AJ, Fantuzzi G, Shapiro L, Muhl H, et al. Overview of interleukin-18: more than an interferon-gamma inducing factor. Journal of leukocyte biology. 1998;63(6):658-64.

248. Mirchandani AS, Salmond RJ, Liew FY. Interleukin-33 and the function of innate lymphoid cells. Trends in immunology. 2012;33(8):389-96.

249. Zhou W, Guo S, Gonzalez-Perez RR. Leptin pro-angiogenic signature in breast cancer is linked to IL-1 signalling. British journal of cancer. 2011;104(1):128-37.

250. Miyoshi Y, Funahashi T, Tanaka S, Taguchi T, Tamaki Y, Shimomura I, et al. High expression of leptin receptor mRNA in breast cancer tissue predicts poor prognosis for patients with high, but not low, serum leptin levels. International journal of cancer Journal international du cancer. 2006;118(6):1414-9.

251. Lee B, Shao J. Adiponectin and energy homeostasis. Reviews in endocrine \& metabolic disorders. 2014;15(2):149-56.

252. Vona-Davis L, Rose DP. Adipokines as endocrine, paracrine, and autocrine factors in breast cancer risk and progression. Endocrine-related cancer. 2007;14(2):189-206.

253. Miyoshi Y, Funahashi T, Kihara S, Taguchi T, Tamaki Y, Matsuzawa Y, et al. Association of serum adiponectin levels with breast cancer risk. Clinical cancer research : an official journal of the American Association for Cancer Research. 2003;9(15):5699-704. 
254.

Hong SC, Yoo SW, Cho GJ, Kim T, Hur JY, Park YK, et al. Correlation between estrogens and serum adipocytokines in premenopausal and postmenopausal women. Menopause. 2007;14(5):835-40.

255. Pajvani UB, Du X, Combs TP, Berg AH, Rajala MW, Schulthess T, et al. Structurefunction studies of the adipocyte-secreted hormone Acrp30/adiponectin. Implications fpr metabolic regulation and bioactivity. The Journal of biological chemistry. 2003;278(11):9073-85.

256. Han C, Zhang HT, Du L, Liu X, Jing J, Zhao X, et al. Serum levels of leptin, insulin, and lipids in relation to breast cancer in china. Endocrine. 2005;26(1):19-24.

257. Aberg UW, Saarinen N, Abrahamsson A, Nurmi T, Engblom S, Dabrosin C. Tamoxifen and flaxseed alter angiogenesis regulators in normal human breast tissue in vivo. Plos one. 2011;6(9):e25720.

258. Hoffman HM, Throne ML, Amar NJ, Sebai M, Kivitz AJ, Kavanaugh A, et al. Efficacy and safety of rilonacept (interleukin-1 Trap) in patients with cryopyrin-associated periodic syndromes: results from two sequential placebo-controlled studies. Arthritis and rheumatism. 2008;58(8):244352.

259. Lachmann HJ, Kone-Paut I, Kuemmerle-Deschner JB, Leslie KS, Hachulla E, Quartier P, et al. Use of canakinumab in the cryopyrin-associated periodic syndrome. The New England journal of medicine. 2009;360(23):2416-25.

260. Jain RK, Duda DG, Clark JW, Loeffler JS. Lessons from phase III clinical trials on antiVEGF therapy for cancer. Nature clinical practice Oncology. 2006;3(1):24-40.

261. Wu H-C, Huang C-T, Chang D-K. Anti-angiogenic therapeutic drugs for treatment of human cancer. J Cancer Mol. 2008;4(2):37-45. 


\section{Papers}

The articles associated with this thesis have been removed for copyright reasons. For more details about these see:

http://urn.kb.se/resolve?urn=urn:nbn:se:liu:diva-117983 